\title{
Elucidation of molecular and hormonal background of early growth cessation and endodormancy induction in two contrasting Populus hybrid cultivars
}

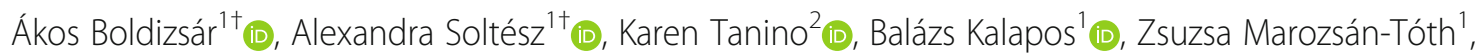
István Monostori ${ }^{1}$ (D) Petre Dobrev $^{3}$ (D) Radomira Vankova ${ }^{3}$ (D) and Gábor Galiba ${ }^{1,4^{*}}$ (D)

\begin{abstract}
Background: Over the life cycle of perennial trees, the dormant state enables the avoidance of abiotic stress conditions. The growth cycle can be partitioned into induction, maintenance and release and is controlled by complex interactions between many endogenous and environmental factors. While phytohormones have long been linked with dormancy, there is increasing evidence of regulation by DAM and CBF genes. To reveal whether the expression kinetics of CBFs and their target PtDAM1 is related to growth cessation and endodormancy induction in Populus, two hybrid poplar cultivars were studied which had known differential responses to dormancy inducing conditions.

Results: Growth cessation, dormancy status and expression of six PtCBFs and PtDAM1 were analyzed. The 'Okanese' hybrid cultivar ceased growth rapidly, was able to reach endodormancy, and exhibited a significant increase of several PtCBF transcripts in the buds on the 10th day. The 'Walker' cultivar had delayed growth cessation, was unable to enter endodormancy, and showed much lower CBF expression in buds. Expression of PtDAM1 peaked on the 10th day only in the buds of 'Okanese'. In addition, PtDAM1 was not expressed in the leaves of either cultivar while leaf CBFs expression pattern was several fold higher in 'Walker', peaking at day 1. Leaf phytohormones in both cultivars followed similar profiles during growth cessation but differentiated based on cytokinins which were largely reduced, while the Ox-IAA and IP7G increased in 'Okanese' compared to 'Walker'. Surprisingly, ABA concentration was reduced in leaves of both cultivars. However, the metabolic deactivation product of ABA, phaseic acid, exhibited an early peak on the first day in 'Okanese'.

(Continued on next page)
\end{abstract}

\footnotetext{
* Correspondence: galiba.gabor@atk.hu

${ }^{+}$Ákos Boldizsár and Alexandra Soltész contributed equally to this work.

'Department of Plant Molecular Biology, Agricultural Institute, Centre for Agricultural Research, ELKH, Martonvásár H-2462, Hungary

${ }^{4}$ Festetics Doctoral School, Georgikon Campus, Szent István University, Keszthely H-8360, Hungary

Full list of author information is available at the end of the article
}

(c) The Author(s). 2021 Open Access This article is licensed under a Creative Commons Attribution 4.0 International License, which permits use, sharing, adaptation, distribution and reproduction in any medium or format, as long as you give appropriate credit to the original author(s) and the source, provide a link to the Creative Commons licence, and indicate if changes were made. The images or other third party material in this article are included in the article's Creative Commons licence, unless indicated otherwise in a credit line to the material. If material is not included in the article's Creative Commons licence and your intended use is not permitted by statutory regulation or exceeds the permitted use, you will need to obtain permission directly from the copyright holder. To view a copy of this licence, visit http://creativecommons.org/licenses/by/4.0/ The Creative Commons Public Domain Dedication waiver (http://creativecommons.org/publicdomain/zero/1.0/) applies to the data made available in this article, unless otherwise stated in a credit line to the data. 


\begin{abstract}
(Continued from previous page)
Conclusions: Our results indicate that PtCBFs and PtDAM1 have differential kinetics and spatial localization which may be related to early growth cessation and endodormancy induction under the regime of low night temperature and short photoperiod in poplar. Unlike buds, PtCBFs and PtDAM1 expression levels in leaves were not associated with early growth cessation and dormancy induction under these conditions. Our study provides new evidence that the degradation of auxin and cytokinins in leaves may be an important regulatory point in a CBF-DAM induced endodormancy. Further investigation of other PtDAMs in bud tissue and a study of both growth-inhibiting and the degradation of growth-promoting phytohormones is warranted.
\end{abstract}

Keywords: Endodormancy, Growth cessation, PtCBFs, PtDAM1, Gene expression, Plant hormone, Populus

\section{Key message}

Differential timing and expression levels of the key regulatory genes $C B F s$ and $D A M 1$ in buds and downregulation of cytokinins and IAA, and ABA metabolism in leaves might be involved in the regulation of growth cessation and dormancy development in vegetative buds of contrasting Populus cultivars differentially sensitive to low night temperature.

\section{Background}

The synchrony of the plant with its environment enables adapted temperate perennial plants to avoid injury. In these northern, temperate regions, growth cessation is a necessary pre-requisite to cold acclimation and subsequent freezing stress resistance $[1,2]$. The growth cycle is regulated by dormancy and in turn, dormancy is governed by both inherent but also environmental factors. While shortening photoperiod has long been known as the most important driver to woody plant dormancy induction [3-6], the temperature has also been and is increasingly recognized as a strong mediator of this response $[7,8]$ for a review see Tanino et al. (2010) [9]. With global warming, more attention is being paid to temperature and its impact on the dormancy cycle. In this regard, research on forest and agroforest tree species have increasingly highlighted the impact of temperature on dormancy [10-13] and photosynthetic capacity [14]. In North America, with its wide adaptation and fast growth, Populus hybrids are the major agroforestry tree of choice in managed lands. Evaluating the impact of future climate change on Populus dormancy cycle is important to select cultivars which are better adapted to fluctuating temperatures.

Dormancy in temperate trees is divided into three phases: paradormancy, endodormancy and ecodormancy [15]. Bud dormancy is defined as 'the temporary suspension of visible growth of any plant structure containing a meristem' [15]. Paradormancy is defined as growth cessation controlled by physiological factors within the plant but external to the affected structure, endodormancy is defined as growth cessation controlled by physiological factors internal to the affected structure, and ecodormancy represents growth cessation controlled by environmental factors external to the plant [16]. Thus, the various types of dormancy in plants constitute a vast field of study. However, because of the impact of the autumn dormancy induction period on other components of the annual growth cycle [17], and the demonstration that temperature mediates timing and depth of dormancy in Populus hybrids [13], in this paper, we will focus on these two aspects.

Furthermore, excellent review papers have focused on the molecular changes, gene regulatory pathways, and hormonal regulations during dormancy [18-25], but relatively less is known about the potential role of $\mathrm{C}$ Repeat Binding Factors (CBFs) in dormancy and Dormancy-Associated MADS-box (DAM) genes in Populus hybrid cultivars widely used in agroforestry systems.

CBF genes, first described in Arabidopsis [26-28], are among the best-characterized plant transcription factors involved in plant abiotic stress tolerance, especially in cold acclimation. The expression of the dehydrationresponsive element binding (DREB) protein/C-repeat binding factor gene $(C B F)$ is rapidly induced by low temperature. The encoded proteins bind to the CRT/ DRE (C-repeat/dehydration responsive element) regulatory DNA motif in the promoters of cold-responsive genes [29], thus inducing their expression, which results in an enhanced cold or frost tolerance [30]. CBFs have been described in a huge number of species, both monoand dicots. Usually several or many gene family members have been identified in one species. Moreover, the number of $C B F$ genes may vary even in the same species, in a genotype-dependent manner (copy number variation). Many $C B F \mathrm{~s}$ were described in the monocotyledonous cereals (some 40 in bread wheat /Triticum aestivum/, 20 in barley /Hordeum vulgare/). Although fewer were described in woody species, their genome also encodes several (3-6) CBF genes. Their involvement in cold adaptation has also been confirmed. A recent review [24] summarizes the genetic regulation of cold hardiness in trees. 
It is becoming more evident that $C B F$ genes are also involved in dormancy regulation, especially in the development of endodormancy [31-34]. Benedict et al. (2006) studied the kinetics and tissue specificity of $4 C B F$ s identified from Populus balsamifera subsp. trichocarpa and concluded that $C B F \mathrm{~s}$ are involved in dormancy development and that their differential expression ensures specific roles for these 'master-switches' in the different annual and perennial tissues [35].

The existence of CBF - DAM - dormancy 'pathway' has been suggested and, at least partially, shown by several studies in Japanese pear $[36,37]$ and Japanese apricot [38]. In his review, Horvath (2009) proposed a theoretical model, 'which can be developed that could serve as a paradigm for further testing' [39]. Wisniewski et al. (2011) demonstrated that transgenic apple (Malus $\mathrm{x}$ domestica) plants, expressing a peach (Prunus persica) $P p C B F 1$ gene showed not only an increased level of freezing tolerance, but also a modified response to short photoperiod, leading to the early onset of dormancy, early leaf senescence, and delayed bud break [31]. As a next step Wisniewski et al. (2015) analyzed CBFs, DAMs, $R G L s$, and $E B B$ transcription factor genes, involved in the regulation of dormancy [32]. The expression of several apple $D A M$ genes - already associated with dormancy development in woody Rosaceae plants exhibited different expression patterns. CBF binding sites identified in the apple $D A M$ promoters led to the suggestion of a regulatory model connecting $C B F s$ and $D A M$ s expression to endodormancy development [32]. $D A M$ genes were first identified in Prunus. A mutant peach, called 'ever-growing', was unable to enter endodormancy even when plants were exposed to short photoperiods or low temperatures [40-42].

$D A M$ genes are members of the type II (MIKCc) subfamily of MADS-box transcription factors. Their sequences contain four major domains, the MADS-box $(\mathrm{M})$, intervening (I-), keratin-like (K-), and C-terminal (C-) domain. These domains are responsible for DNA binding, protein dimerization, complex formations, and transcriptional regulation. A detailed structural and functional characterization of $D A M$ genes can be found in the reviews published by Horvath (2015) and Falavigna et al. (2019) [43, 44]. In this latter publication, a model is proposed, introducing the molecular network of the regulatory genes involved in the dormancy cycle.

Expression patterns of the DAM genes were related to endodormancy and were mainly presented in the Prunus genus, among them peach ( $P$. persica) ever-growing [45] and peach cultivars [46], Japanese apricot ( $P$. mume) [47], and also in apple [48] or Japanese pear (Pyrus communis) [49, 50]. DAM gene expression appears to be linked to the stage of dormancy (see Falavigna et al. (2019) for a review [44]). In most species, DAM gene expression is induced during the dormancy induction period but may also be involved in maintenance and release [46]. Based on amino acid sequence, poplar DAM1 and $D A M 2$ expression were most closely associated with leafy spurge MADS 27-29 and unlike the other DAM genes, $D A M 1$ and $D A M 2$ were upregulated by dormancy inducing short-day conditions in poplar (Chen (2008) [51] as cited by Horvath et al. (2010) [52]). Interestingly in a later transcriptome study these results were not confirmed. Howe et al. (2015) examined several DAMlike genes that were downregulated during endodormancy [53]. One of the examined genes was the Potri.002G105600, but in this study, the authors did sampling only once per month.

Analysis of transgenic plants showed $C B F$ genes were also involved in the regulation of endodormancy. The ectopic expression of a peach $P p C B F 1$ gene in apple resulted in short-day induced dormancy and increased cold hardiness [31], and affected the expression levels of apple MdDAM1 and MdDAM3 genes in buds [32]. Li et al. (2019) analyzed pear (Pyrus pyrifolia) $C B F$ and $D A M$ genes and found multiple $C B F$ genes selectively regulate $D A M$ genes and participate in endodormancy regulation [37]. Interestingly, this group found that "PpCBF1-PpDAM2 regulon mainly responds to low temperature during endodormancy regulation, with further post-translational regulation by PpICE3". In addition, the expression of ParCBF1 was found to be in close association with the decreasing ambient temperatures in apricot (Prunus armeniaca), and the expression levels of ParDAM5 and ParDAM6 changed according to ParCBF1 expression rates [54].

Molecular evidence also supports the CBF - DAM connection. The presence of CBF transcription binding sites was reported in the putative promoter regions of the leafy spurge $D A M$ genes [52]. A model, illustrating a potential interaction between DREBs (CBFs) and DAMs was subsequently suggested [55]. An interaction of PpCBF2 protein with the promoter of PpMADS13-1 gene was shown in pear by transient reporter assay [56]. Also in pear, yeast one-hybrid and transient assays showed that PpCBF2 enhanced PpDAM1 and PpDAM3 transcriptional activity during the induction of dormancy [38]. Zhao et al. (2018) showed that P. mume CBFs can bind to the PmDAM6 promoter via alternative binding sites and activate its expression [33, 34]. Japanese pear $P p C B F$ s were able to induce the expression of PpDAM1-1 and PpMADS13-3 genes in transient reporter assays [56]. Different biochemical methods revealed that pear $P p C B F 2$ and $P p C B F 4$ genes are able to bind to the promoter of $P p D A M 1$ gene, activating its expression, and revealed that $P p C B F 1, P p C B F 2, P p C B F 3$, $P p C B F 4$ genes can activate $P p D A M 3$ gene [37]. These 
results demonstrate the CBF - DAM signalling pathway is involved in endodormancy development and also demonstrate a certain level of $C B F$ functional redundancy.

Herein we use a system of two contrasting Populus hybrid cultivars differing in growth cessation and dormancy acquisition which were previously distinguished based on low night temperature under short photoperiod. The hypothesis that growth cessation and dormancy induction is linked to leaf phytohormone levels, bud PtDAM1 and bud PtCBFs gene expression in Populus will be evaluated.

\section{Results and discussion}

In our previous work [13] we studied the impact of temperature on growth cessation, dormancy development, and cold acclimation of four poplar cultivars. These temperature regimes changed the kinetics of dormancy development patterns with the $18 / 3^{\circ} \mathrm{C}$ treatment inducing the widest separation of dormancy depth. Therefore, to elucidate if there is a relationship between the expression levels of $C B F$ genes and dormancy in poplar, two cultivars differing in their dormancy acquirement based on night temperature responses were tested under short-day conditions in our current research.

\section{Dormancy development}

Growth cessation

Growth cessation is the first indication of dormancy induction [57] and was induced in both genotypes (Fig. 1). Consistent with Kalcsits et al. (2009), a significantly earlier and steeper drop could be observed in the 'Okanese' compared to 'Walker' cultivar, between the 3rd and the 4th week of dormancy inducing conditions. After the 5 th week, no further growth was recorded. 'Walker' showed higher growth rate at every time-point, with the exception of the 1st week. By the end of the experiment, no significant difference was found between these two cultivars $\left(0.36\right.$ and $0.51 \mathrm{~cm}{ }^{*}$ week $^{-1}$ in Okanese and Walker, respectively).

\section{Dormancy induction}

While growth cessation was a more sensitive indicator, significant differences in the number of days to bud break were found between the two cultivars from day 40 (Fig. 2). Okanese buds took 10 days to break bud at Day 0 , while at the end of the experiment (i.e. on the 50th and 60th day) this value was increased and levelled off at 13.5 and 14.1 days (respectively). Conversely, the duration of bud break was hardly changed in 'Walker' over the whole 60 days treatment period, just a slight fluctuation was recorded (Fig. 2). No difference was detected

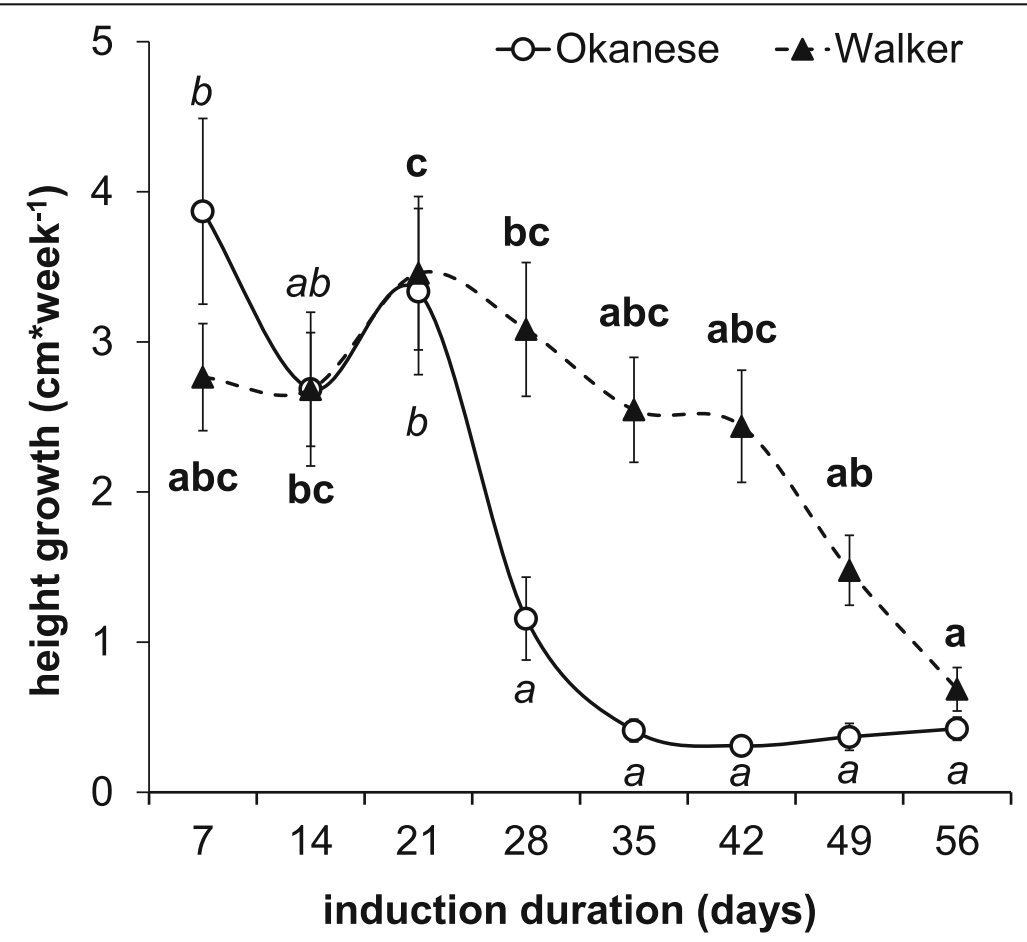

Fig. 1 Shoot length increments ( $\mathrm{cm}^{*}$ week $\left.^{1}\right)$ in the Okanese (circle) and Walker (triangle) cultivars under SD conditions (12/12 h, light/dark period) at $18 / 3^{\circ} \mathrm{C}$ temperature during the first 30 days, then $10 / 14 \mathrm{~h}$ for an additional 30 days. Error bars represent the \pm SEM. $N=27$. The values indicated by different letters are significantly different at $P<0.05$ level from each other 


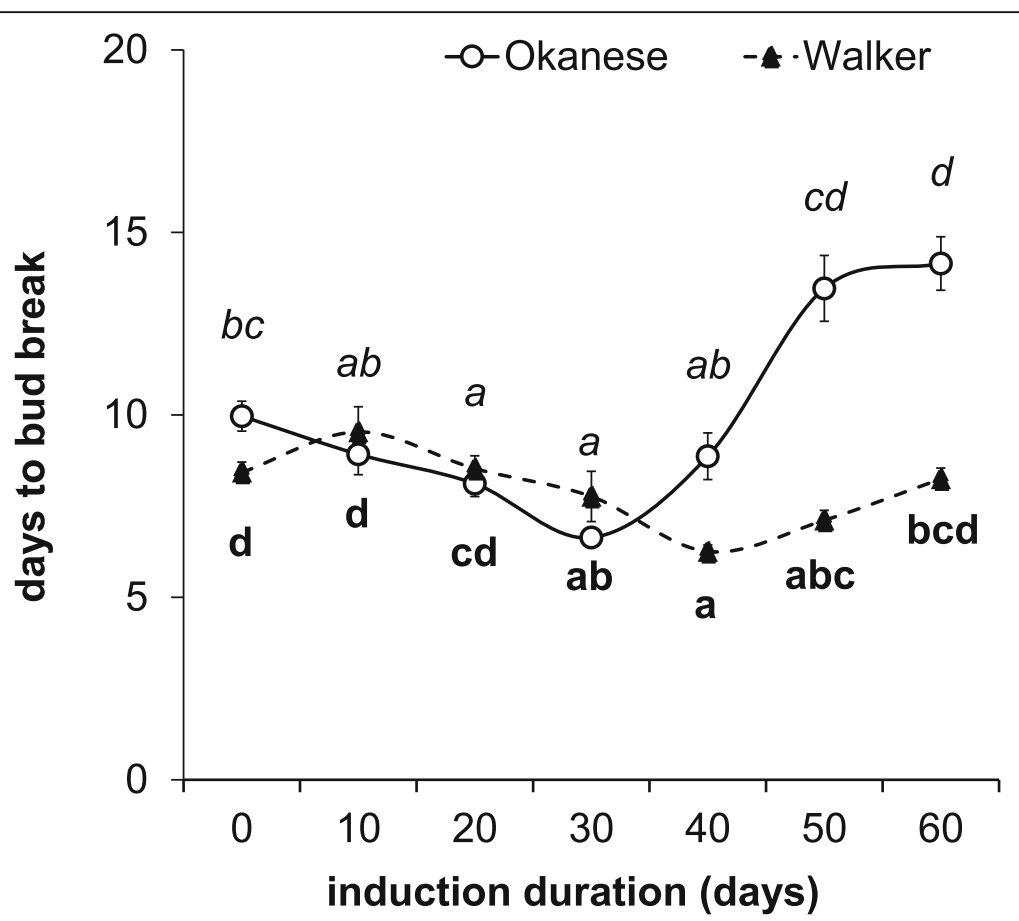

Fig. 2 Dormancy development (characterized as days to bud break) of Okanese (circle) and Walker (triangle) cultivars under SD conditions (12/12 $\mathrm{h}$, light/dark period) at $18 / 3^{\circ} \mathrm{C}$ temperature during the first 30 days, then $10 / 14 \mathrm{~h}$ for an additional 30 days. Error bars represent the \pm SEM. $N=40$. Different letters indicate statistically different $(P<0.05)$ number of days for the given cultivar

between the first and the last days (days to bud break: 8.4 and 8.2 days, respectively).

The depth of dormancy was reflected by the parameter $\triangle \mathrm{DBB}$ (Differences between the first and last Days to Bud Break) and dormancy was not induced at all in 'Walker' $(\triangle \mathrm{DBB}=0.2)$. Conversely in 'Okanese', the dormant state started to be induced after 30 days. At the end of the experiment, Okanese had a $\triangle \mathrm{DBB}$ of 4.1 (Fig. 2 ). The data on growth cessation rate and the bud break analysis indicates that 'Okanese' reached a deeper dormant state than 'Walker'. Our results are consistent with the outcome of Kalcsits et al. (2009) [13], who reported characteristic differences between these two cultivars 'Okanese' was shown to be more capable of endodormancy development under the $18 / 3^{\circ} \mathrm{C}$ day/night temperature treatment under $12 \mathrm{~h}$ and $10 \mathrm{~h}$ daylengths although a larger difference was found between the two cultivars ( $\triangle \mathrm{DBB}: 13.9)$ in that study.

\section{Expression pattern of $C B F$ genes}

The expression patterns of six $C B F$ genes were recorded over the whole experiment. Samples were collected from leaf and bud tissues every ten days, taking into account the circadian rhythms of many $C B F \mathrm{~s}$, in the same period of the day, i.e. $4-6 \mathrm{~h}$ after the start of the light period. The expression of each gene in a given time-point was normalized to the level measured at the beginning (i.e. on the 0 day) of the given treatment.
Differences in the kinetics and spatial localization of the overall $C B F$ expression were observed between the two cultivars. The highest levels of $C B F$ expression across the entire experiment were recorded in the bud tissue, isolated from 'Okanese' on the 10th day (Fig. 3a) and on the first day in 'Walker' leaf samples (Fig. 3d). The expression levels in 'Okanese' poplar buds peaked at the 10th day and were at least an order of magnitude (10-20 fold) higher than in 'Walker' buds, and at any other time during the experiment for all the $C B F \mathrm{~s}$ (with the exception of PtCBF5). There was differential expression of bud PtCBFs between the two cultivars in that PtCBF1 and PtCBF5 showed the highest and lowest expression in 'Okanese' buds, respectively, while the reverse was observed in 'Walker'. In 'Walker' leaves on the 1st day, PtCBF1 and PtCBF2 expression levels were roughly equivalent to 'Okanese', however, 'Walker' leaf expression of PtCBF3, PtCBF4, PtCBF5 and PtCBF6 spiked on the 1st day and were 150-200 times greater than 'Okanese' (Fig. 3c, d).

The expression patterns of the unique $C B F$ genes are described in detail in the Supplemented Fig. 1. In bud tissue, PtCBF2, PtCBF3 and PtCBF5 were induced only in the beginning of the experiment, on the 10th day, while PtCBF1 and PtCBF6 were induced not only at the beginning but also at the end of the treatment, on the 50th and 60th (PtCBF1) or on the 40th day (PtCBF6). The induction level was always an order of magnitude 


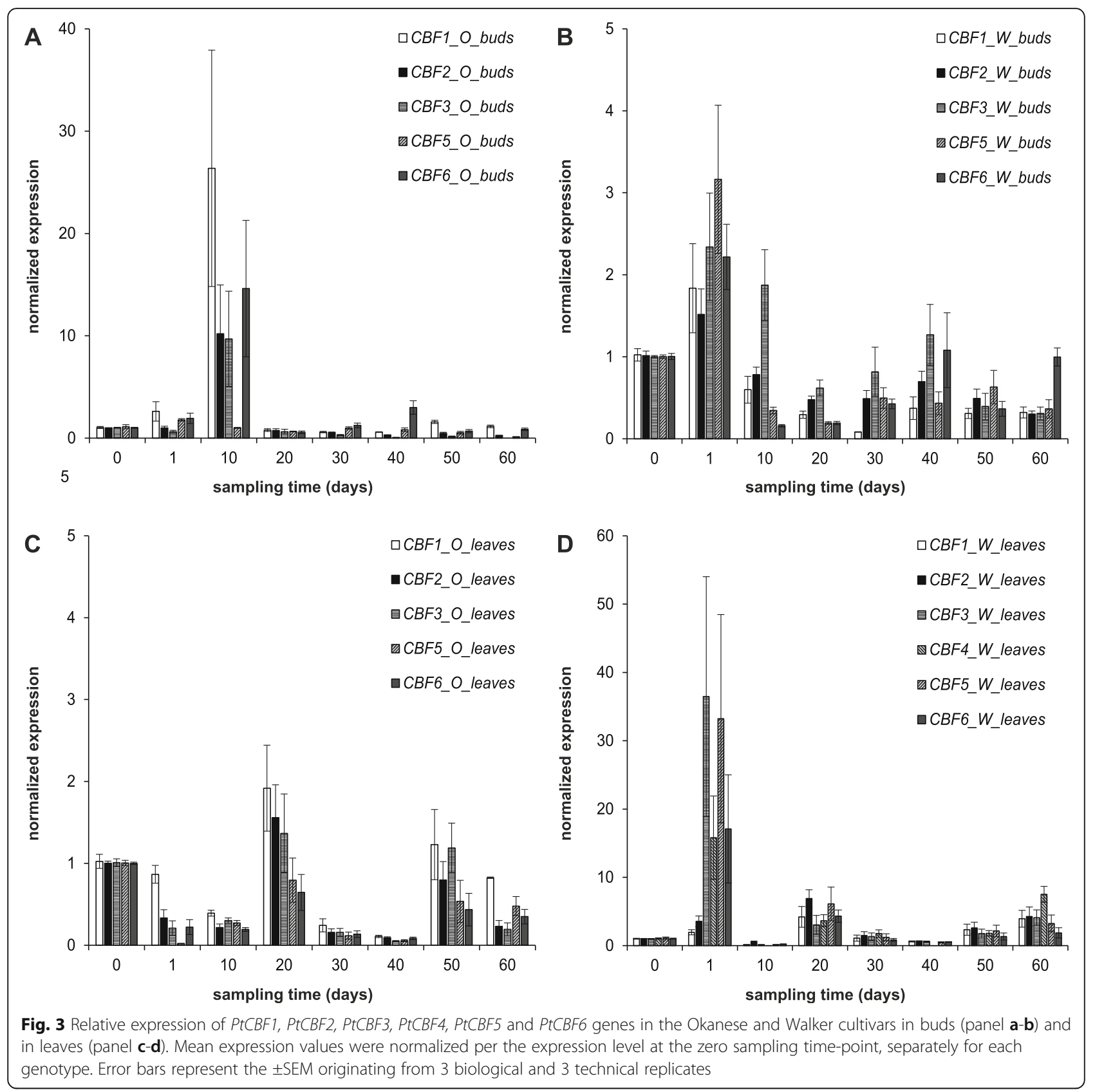

higher in the 'Okanese' buds compared to 'Walker' for each $C B F$. The repression of $C B F$ genes was more pronounced in the 'Walker' buds. A repressed period was recorded in the middle of the experiment for PtCBF1, PtCBF5 and PtCBF6 genes in 'Walker' buds, while only one repressed stage was found in 'Okanese' in the mid period of $P t C B F 3$ expression (Supp. Figure 1A, D, E and C).

By contrast in leaf tissue, two induction waves could be observed in the leaf samples for all CBFs in 'Walker': the first was at the beginning (on the 1st and 20th day), while the second was at the end (50th and 60th day).
Induction waves were also found in 'Okanese' leaves, but in the opposite direction, since repression of all $C B F \mathrm{~s}$ was detected in the period 1st-10th and 30th-40th and finally on the 60th day. It is interesting to note the differential responses between the cultivars in leaf tissues in that CBF induction was found in 'Walker' leaves, while repression was found almost in every case in 'Okanese' leaves (Supp. Figure 1F-K). Thus, these two cultivars had similar but opposite PtCBF expression under dormancy inducing conditions based on buds or leaves.

Differences in the $C B F$ expression kinetics and levels measured in the meristematic (bud, stem) and leaf 
tissues were studied in several cases in woody plants, among them poplar. Benedict et al. (2006) described different $C B F$ induction patterns in P. balsamifera Ss $p$. trichocarpa showing that all four $P t C B F \mathrm{~s}$ are coldinducible in leaves, while only two (PtCBF1 and PtCBF3) were cold induced in the stem [35]. Under a shortexpression period $(24 \mathrm{~h})$, they concluded, 'the perennial driven evolution of winter dormancy led to the development of specific roles for abiotic stress response regulators, such as the $C B F \mathrm{~s}$, in annual and perennial tissues'. $C B F$ expression was followed in leaf and leaf bud tissues in Prunus mume during one year by Zhao et al. (2018) [33]. They also found a differential gene expression pattern for all six $C B F \mathrm{~s}$ studied, with specific induction kinetics. In that study, all six $C B F s$ were induced in vegetative buds, in the cold period (November - January); PmCBF4, PmCBF5 and PmCBF6 being the most intensively expressed. These three $C B F \mathrm{~s}$ were also the most induced in the leaf tissues. But interestingly, in leaves, the highest expression for all $6 C B F \mathrm{~s}$ was recorded during the warmest period, from June to July. This finding is in accordance with our results, i.e. that the $C B F$ expression was much more intense in leaves of the non-dormant cultivar, may indicate that their role in the development in dormancy is organ-specific. Six $P m C B F$ s in 7 different organs were determined in $P$. mume [33]. The induction levels were high in stems, moderate in flower buds, leaf buds, and leaves, poor in flowers, fruits, and seeds.

Gene duplication and multiplication produced a large number of $C B F \mathrm{~s}$ in many species. This redundancy makes possible the divergence of functionality, and the possibility for fine-tuning of adequate response for any environmental stimuli, such as stress. As mentioned above, $6 C B F$ s encoded in the $P$. mume genome exhibited different expression kinetics during the year: $P m C B F 1, P m C B F 2$, and $P m C B F 3$ were up-regulated in the stem tissues not only in the cold period but also in late spring [34]. Additionally, low temperature upregulated $8 C B F \mathrm{~s}$ in Prunus mume which subsequently induced all six $D A M$ genes resulting in dormancy development [36]. Under natural dormancy induction conditions, 3 out of $4 C B F$ s showed similar expression trends in Pyrus pyrifolia bud tissues, while P $P C B F 1$ showed a different induction kinetic [37]. During an artificial chilling test, $P p C B F 1$ was the only $C B F$ highly expressed, while $P p C B F 2$ was repressed intensively, and the levels of $P p C B F 3$ and $P p C B F 4$ were undetectable.

These results show that although $C B F$ expression kinetics may be similar, differences in the individual expression patterns can be distinguished. Shortening the light period by $2 \mathrm{~h} /$ day to account for the variance in nature (at the same temperature regime) may have caused a moderate functional polymorphism in our experiment.
PtCBF4 was detectable only in 'Walker' leaves, while PtCBF1 and PtCBF6 were the most intensively expressed genes in 'Okanese' buds. Whether they have different functions, as was suggested for PpCBF4 [37] in pear, is still unclear. It is also remarkable that PtCBF5 was the only gene which was not induced during the CBF-burst on the 10th day in 'Okanese' buds but was the most intensively up-regulated in 'Walker' buds on the 1st day. Therefore, we assume PtCBF5 is not related to dormancy development.

Leaf samples of Populus balsamifera ssp. trichocarpa genotypes originating from northern and southern populations were examined [58]. A growth chamber study showed all PtCBF genes were induced by cold, indicating functional redundancy. On the other hand, under field conditions, a more diverse gene expression pattern was described. The expression of PtCBFs increased as the growing season progressed, but among the six genes, only $P t C B F 3$ was marginally differentially expressed across latitudes. In our experiment, leaf samples also showed a certain level of functional polymorphism, but the most common outcome of the two systems is that in leaves, no dormancy dependent expression pattern was found, such a relation was present only in the bud tissues.

\section{PtDAM1 identification and its expression kinetics}

DAMs (Dormancy-Associated MADS-Box) are wellcharacterized genes in perennial plants, associated with various components of the dormancy cycle but particularly dormancy induction. DAM sequences had already been published in woody plants, all containing K-box and SRF-TF motifs $[33,59,60]$. The $P$. trichocarpa genome has been sequenced [61], however, it is still poorly annotated. We have found 151 candidates for the DAM genes. From these, we suggested the XP_024452024.1 protein entry (available at the NCBI protein database: https://www.ncbi.nlm.nih.gov/protein/) as a putative PtDAM1 product (Figs. 4 and 5). The XP_024452024.1 entry is corresponds to older versions as MADS7, Potri.002G105600 at the PopGenIE database: https:// popgenie.org/). Howe et al. (2015) studied transcriptome changes during endodormancy induction by microarray in P. trichocarpa and found several DAM-like SVP genes were differentially expressed but were downregulated during endodormancy [53]. Since sampling was conducted on a once per month basis, it is not clear if upregulated peaks were missed.

Having identified a PtDAM1 gene in Populus, we decided to evaluate its potential role in dormancy development, using cultivars known to be differentially responsive to night temperatures. Therefore, primers were developed to study the encoding PtDAM1 gene expression. Compared to the first sampling day, mild up- 


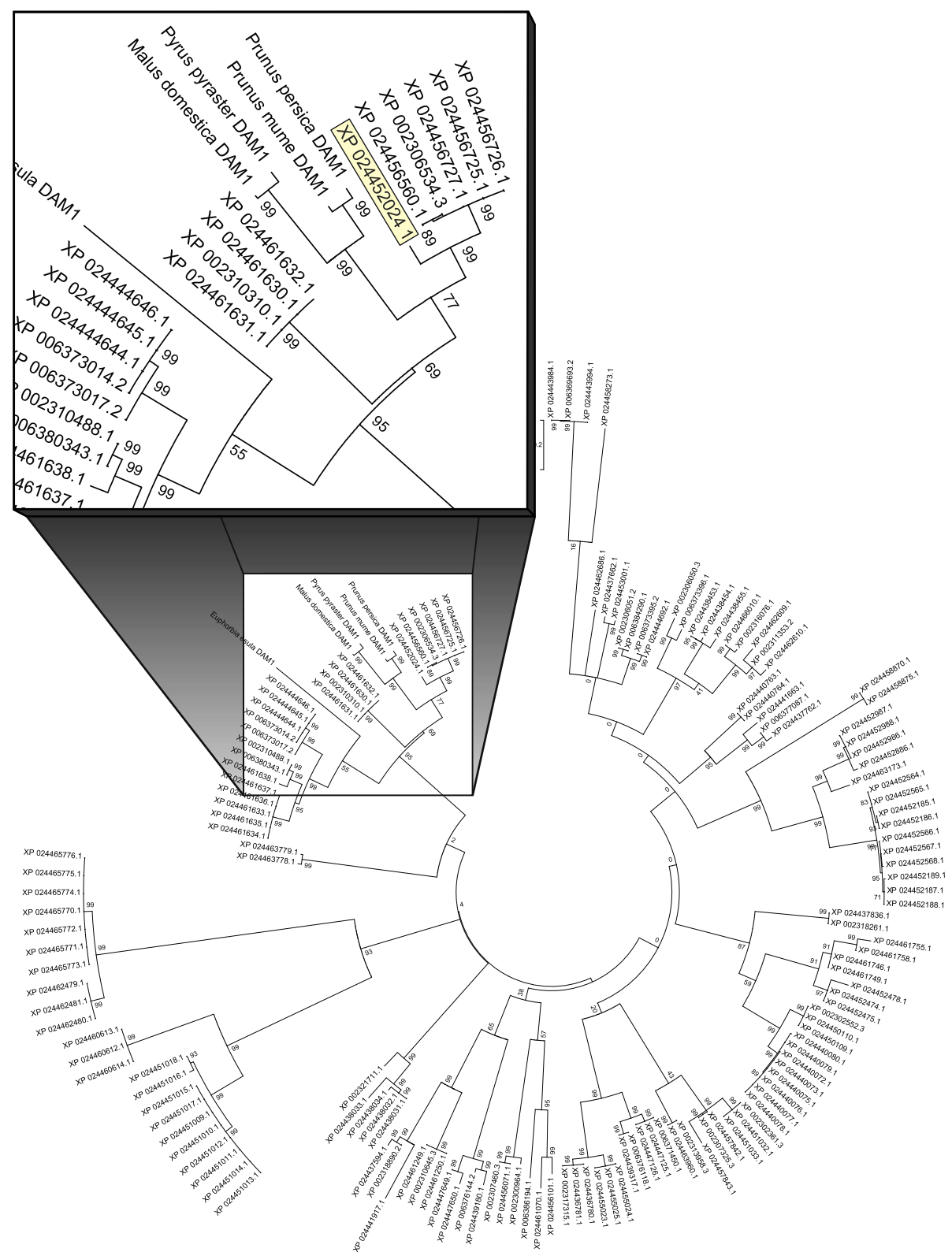

Fig. 4 Phylogenetic relationships of PtDAM1 and other DAM proteins containing K-box and SRF-TF domains identified in woody plants. Magnified box shows DAM1 proteins from different plant species where the putative PtDAM1 Populus sequence (XP 024452024.1) is highlighted

regulation of the identified putative XP_024452024.1 sequence was recorded in 'Okanese' leaves through the experiment, while lower induction was found in 'Walker'. PtDAM1 was repressed from the middle of the experiment (Fig. 6) and the expression of PtDAM1 was almost unchanged throughout the 60 days in leaf tissues. The bud tissues showed much more pronounced induction than the leaf tissues. In more dormant 'Okanese', the maximum expression (2.8-fold) was recorded on the 10th day then the induction gradually declined. Repression was recorded in both cultivars at the end of the treatment. PtDAM1 induction in buds was weaker in the first half of the treatment in 'Walker' (1.1-1.6-fold induction) which did not enter endodormancy.

Similar expression trend for PmDAM1 gene was described in Japanese apricot (Prunus mume) bud tissue, but differently in the leaf samples [47]. In the vegetative buds, expression of PmDAM1 (as well as PmDAM2 and $P m D A M 3)$ was upregulated from June to July, i.e. long before the start of growth cessation, then expression started to decrease. We also showed an initial PtDAM1 induction in our system, well before the start of growth cessation, or dormancy development. We found no characteristic changes in leaf tissues, however, in Prunus 


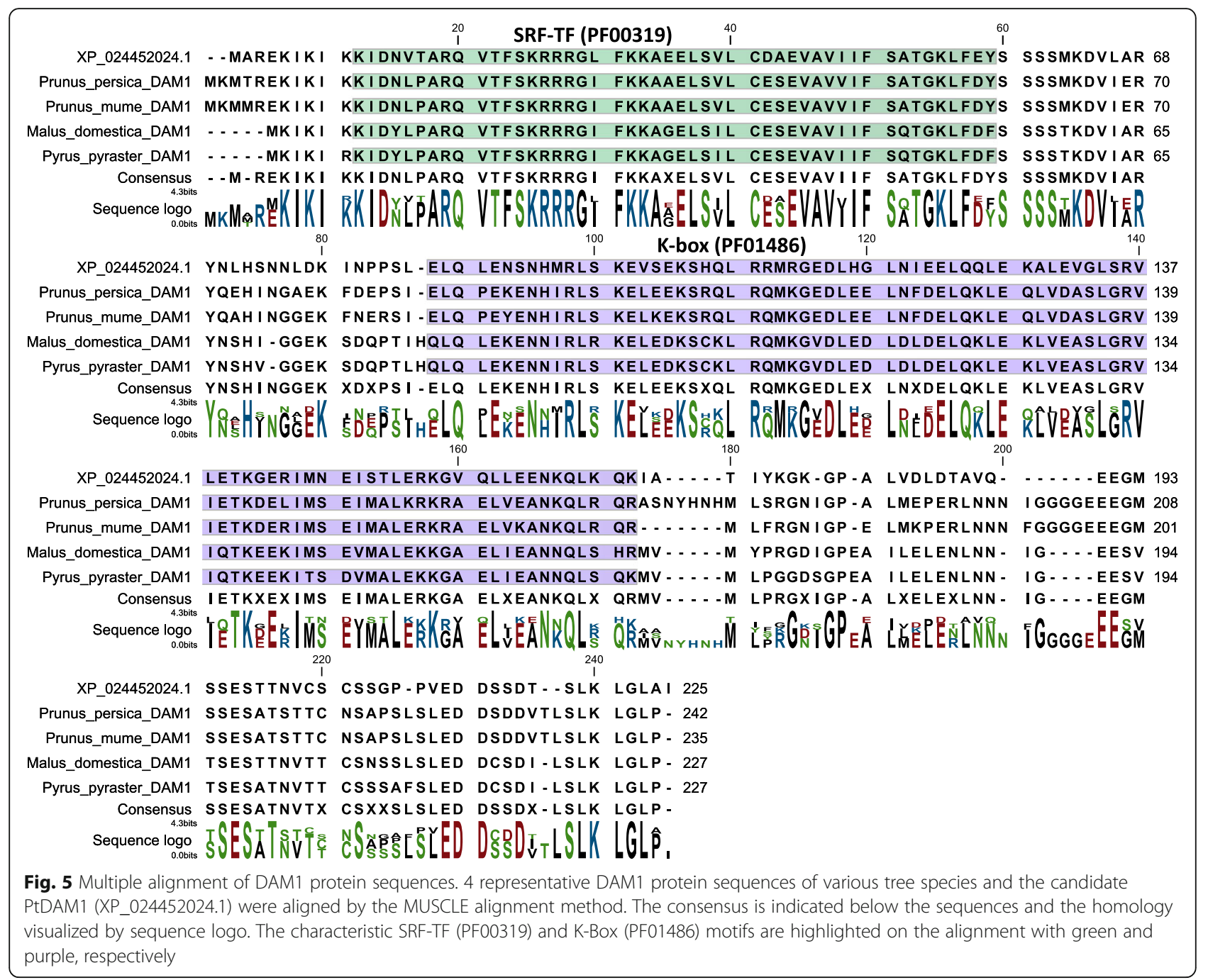

mume, different kinetic patterns were described in this organ [47]. Two seasonal expression trends were shown for P. mume DAMs, PmDAM1 (together with PmDAM2 and $P m D A M 3)$ was rapidly up-regulated in spring, being gradually down-regulated in autumn. This difference in the expression in leaf tissue might be explained by the two different experimental systems. In other studies in peach (Prunus persica), differential DAM gene expression appeared to be related to dormancy induction or fulfillment of the chilling requirement phases. Based on the ever-growing peach mutant system, Li et al. (2009) reported $D A M 1, D A M 2$ and $D A M 4$ were the most likely candidates associated with growth cessation and dormancy induction [45]. Using the same system, Yamane et al. (2011) showed under both field and controlled environment conditions and in leaves and stems, DAM5 and DAM6 gene expression levels were up-regulated during endodormancy induction and downregulated during endodormancy release which appeared to be tied to chilling requirement satisfaction [62]. Furthermore,
$D A M 5$ and DAM6 gene expression levels were higher in high chill cultivars and reduced with chilling requirement satisfaction [63]. DAM5 and DAM6 genes were negative regulators of bud break.

\section{Dynamics of hormone changes during dormancy development}

Phytohormones have been long known to be involved in the dormancy cycle [23, 25, 64-72]. Recently, mechanistic relationships between phytohormones and dormancy are being revealed $[36,73,74]$.

In our study, due to the very small size of poplar buds and only limited capacity of growth chambers, hormone analysis was conducted only in leaf samples. Overall, phytohormonal response in 'Okanese' was different than in the 'Walker' poplar hybrid cultivar with most significant distinction for Ox-IAA, phaseic Acid, DAM1, ciszeatin riboside-O-glucoside (cZROG) (Figs. 7 and 8). Exposure of poplar plants to short photoperiod and low night temperatures was associated with down-regulation 


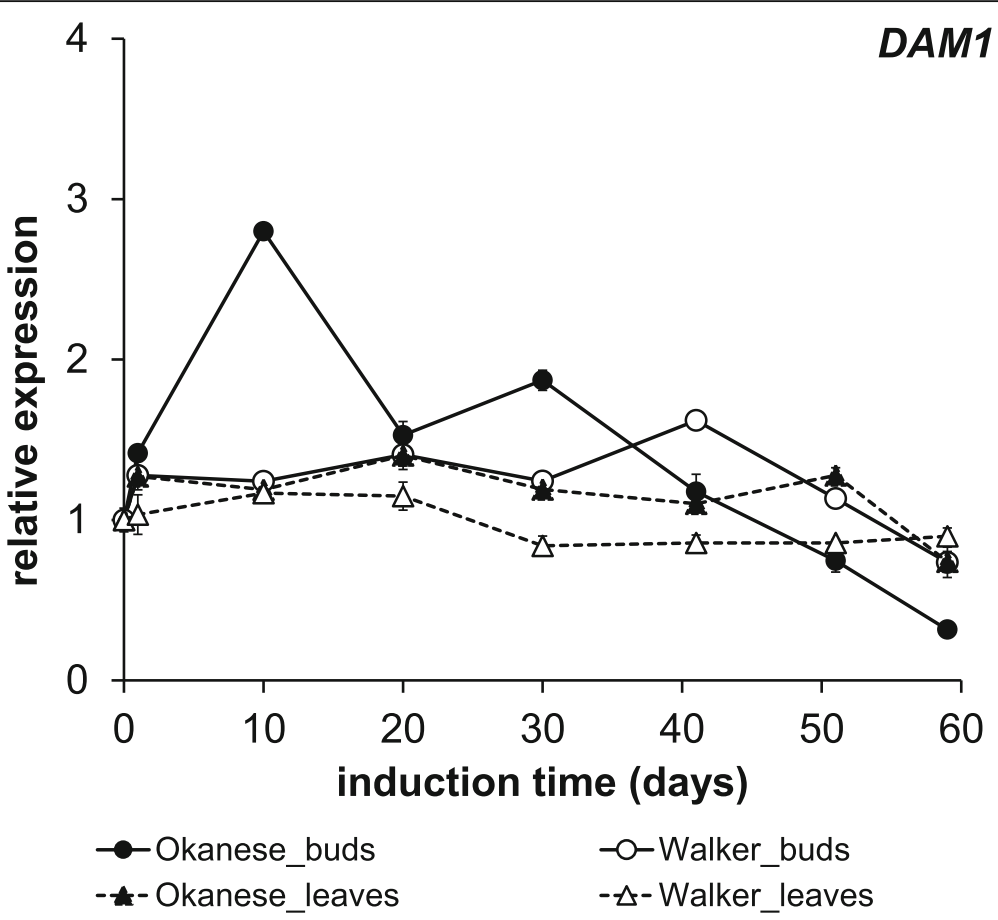

Fig. 6 Relative expression pattern of PtDAM1 gene in the buds and leaves (circle and triangle, respectively) of the Okanese (solid) and Walker (open) poplar cultivars. Error bars represent the SD of the technical replicates

of ABA content in leaves of both genotypes (Fig. 8). However, an early (on the 1st day) transient elevation of the ABA metabolite, phaseic acid, indicated enhanced ABA degradation in the 'Okanese' cultivar, suggesting a preceding short-term up-regulation of $\mathrm{ABA}$ content early after temperature drop. This assumption is supported by the report on transient up-regulation of ABA in cold-stressed wheat leaves [75]. The ethylene

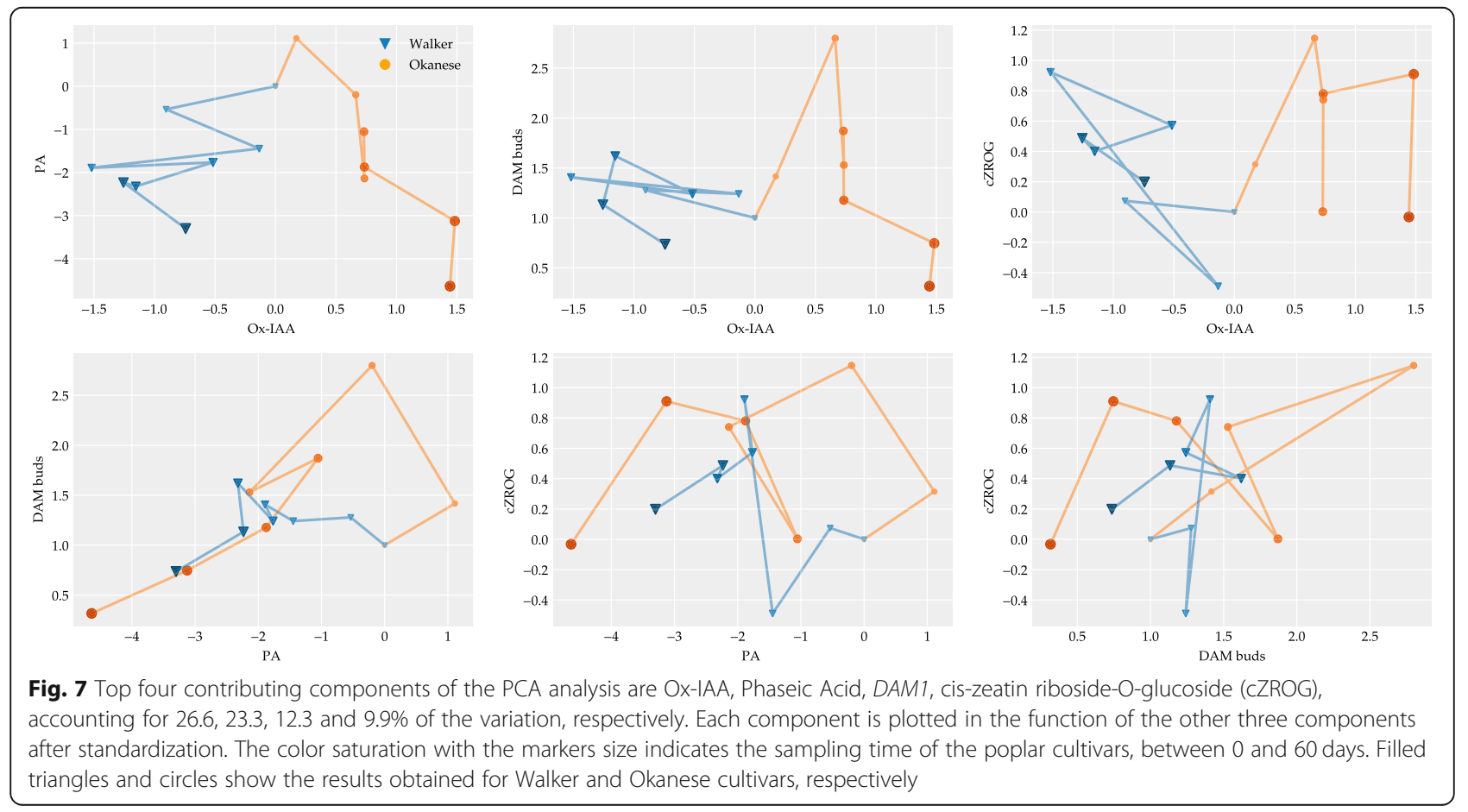




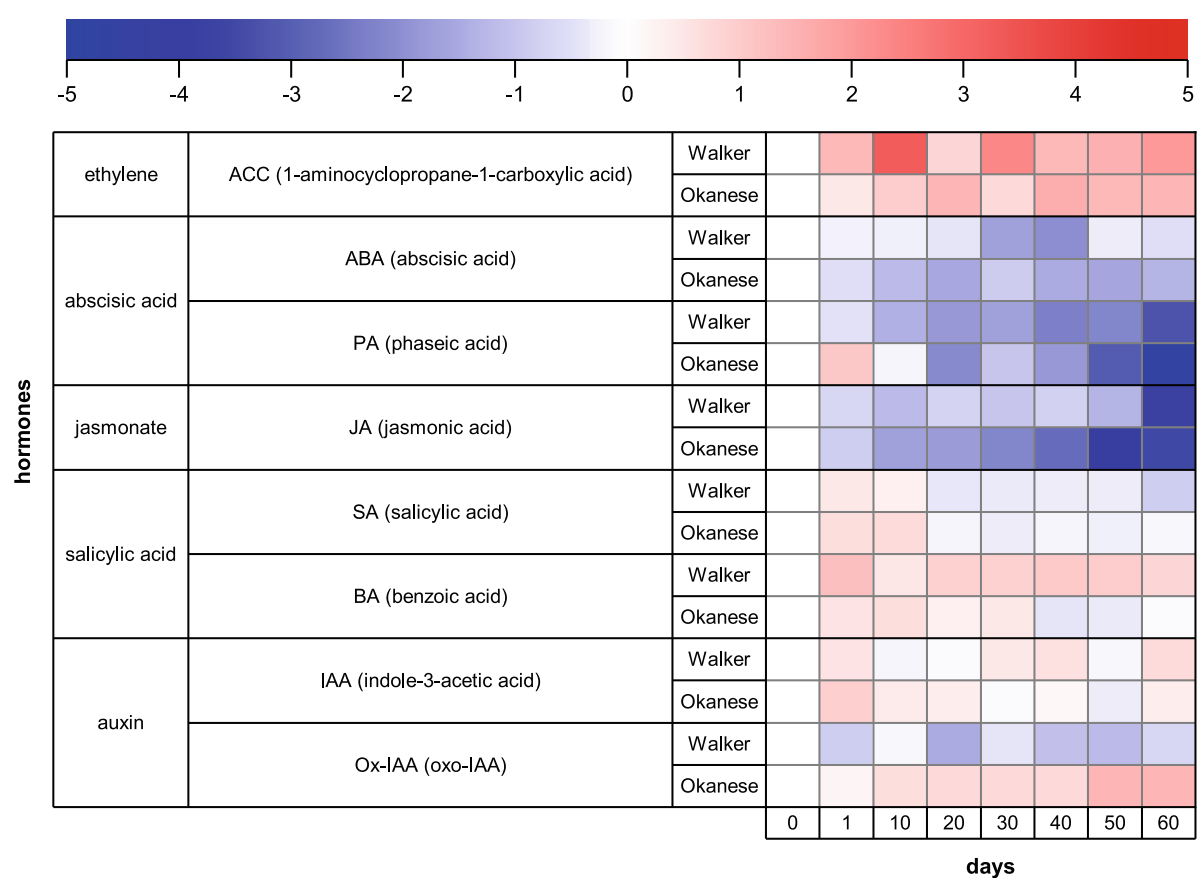

Fig. 8 Heatmap of the levels of ethylene, abscisic acid, jasmonate, salicylic acid, auxin and their metabolites in the leaves of Walker and Okanese poplar cultivars. Colour scale represents the $\log _{2}$ transformation of the ratio between concentration measured at the given sampling time and concentration measured on day 0

precursor ACC was elevated in both clones. Ruttink et al. (2007) showed ethylene rise preceded ABA during dormancy induction [64]. Jasmonate has been known to be involved in several stress responses [76]. Inactivation of the repressors of JA signaling pathway - jasmonate ZIM-domain (JAZ) proteins, which physically interact with ICE1 and ICE2 transcription factors, results in upregulation of $C B F s$ [77]. $C B F$ genes promote gibberellin deactivation and thus growth inhibition [78]. In our study in leaf tissue, JA levels were suppressed in both genotypes during the entire experimental period, and more in 'Okanese'. However, JA level in leaves need not correlate with its content in buds. Moreover, JAZ inactivation may be achieved by their interaction with DELLA proteins $[79,80]$, which accumulate at low temperature and are stabilized by gibberellin down-regulation. In contrast to JA, SA levels were increased at the beginning of the experiment, one week longer in 'Okanese'. This agrees with the positive effect of SA on plant cold tolerance [81]. After the 3rd week, the SA content was unchanged in both cultivars, however, the concentration was lower in the less cold-hardy 'Walker'. Benzoic acid, the precursor of SA and other phenolic compounds, was elevated during the experiment; in 'Okanese' until dormancy initiation, in 'Walker' during the whole experiment. These changes demonstrate differences in hormonal dynamics between the clones during leaf senescence (Fig. 8).
The auxin, indole-3-acetic acid (IAA), had varying levels across the 60-day treatment in both cultivars. However, the main IAA catabolite, Ox-IAA, had a more consistent response, being up-regulated in 'Okanese' and down-regulated in 'Walker', which indicates stronger IAA deactivation in 'Okanese' leaves. Dormancy initiation, associated with substantial suppression of growth rate, was accompanied by IAA downregulation, which was not observed in the nondormant clone (Fig. 8). Baldwin et al. (2000) showed that while the auxin naphthaleneacetic acid was not required for bud scale development, its absence was critical [82].

The whole cytokinin pathway was downregulated in Okanese compared to Walker: the precursors iPRMP and tZR increased only in Walker, the active form (iP) decreased only in Okanese, and the deactivated form iP7G was accumulating in Okanese and decreasing in Walker. Other compounds did not show any major changes between both trees (Fig. 9).

Cytokinin analysis clearly showed that promotion of dormancy in 'Okanese' was associated with a general decrease of cytokinin biosynthesis and profound elevation of their deactivation products in leaves (Figs. 7 and 9, Supp. Figure 2). Collectively, these results provide new evidence that the degradation of growth-promoting phytohormones such as IAA and cytokinins may be an important mechanism of endodormancy induction. 


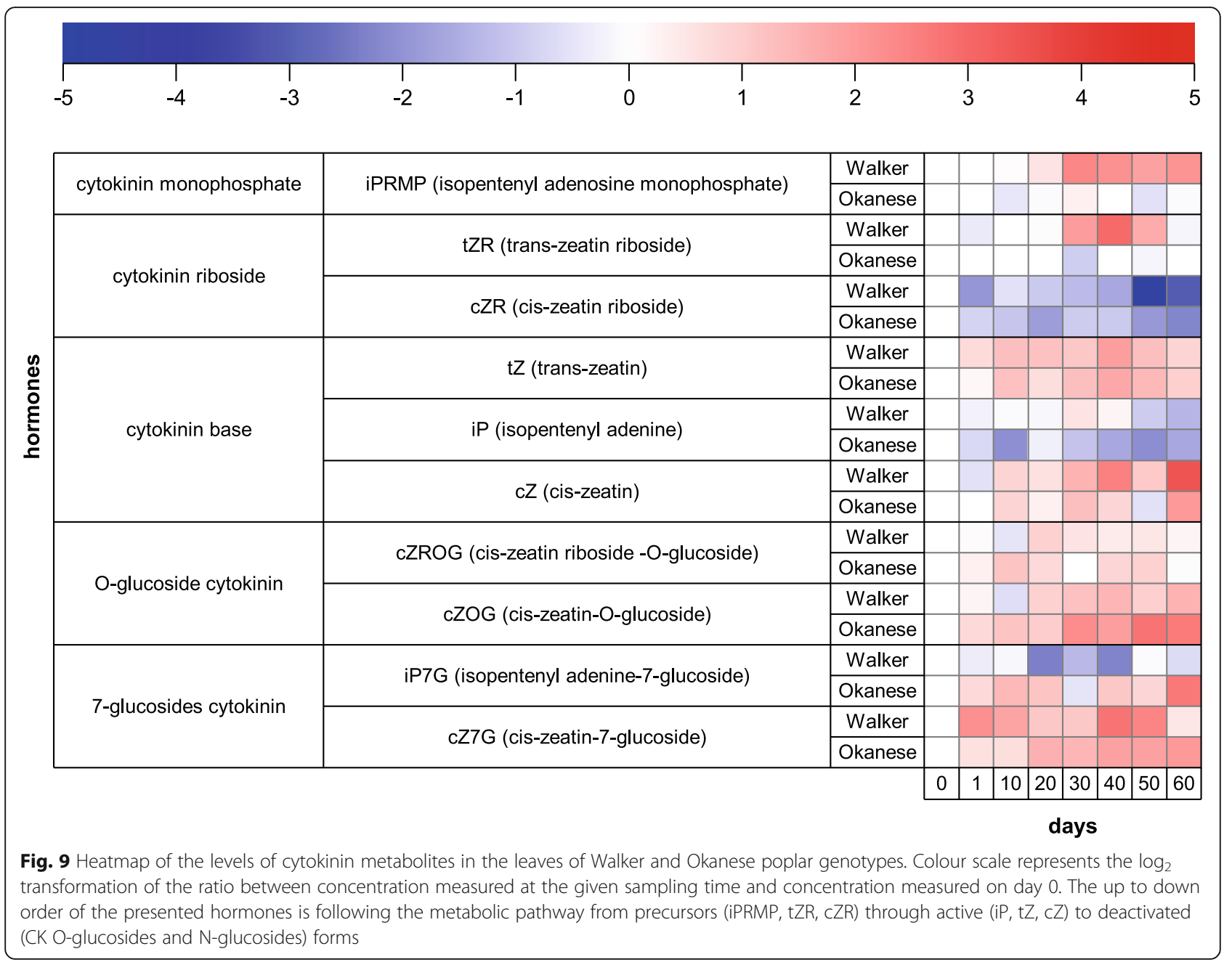

The relation between PtCBFs and PtDAM1 expression, hormone level and the development of dormancy

A CBF-burst occurred on the 10th day of the short photoperiod and low night temperature treatment in 'Okanese' bud tissues, while in 'Walker' CBF levels were an order of magnitude lower (Fig. 3). In 'Okanese' which was able to enter endodormancy (Fig. 2), CBF1 had the highest relative expression at the initiation of dormancy. PtDAM1 expression peaked in 'Okanese' exactly on the same 10th sampling day (Fig. 6). By contrast, 'Walker' which did not attain endodormancy (Fig. 2) had a lower $C B F$ expression on the 1st day (Fig. 3), while PtDAM1 expression was also low and unchanged during the experiment (Fig. 6). Growth rate started to decline in both cultivars by the 3rd week, but at a much faster rate in 'Okanese' (Fig. 1). These findings support the possible relationship between PtCBF1, PtDAM1 induction and endodormancy development.

The dormancy-associated phytohormone, ABA, was surprisingly down-regulated in leaves of 'Walker' and even more downregulated in 'Okanese'. However, the concentration of the ABA degradation intermediate, phaseic acid, increased in 'Okanese' while it was reduced in 'Walker' and therefore, an ABA induction peak in 'Okanese' leaves may have been missed (Fig. 8). Recent evidence indicates a role of DAM1 in activating NCED3 through binding to its promoter and upregulating $\mathrm{ABA}$ biosynthesis in Japanese pear [83]. The same study found high concentrations of $\mathrm{ABA}$ can also reduce DAM1 in a feedback regulatory loop. DAM proteins are similar to SVP (Short Vegetative Phase), one of the flowering time regulators in Arabidopsis. In kiwifruit, $\mathrm{Wu}$ et al. (2017) [84] performed a transcriptomic analysis and found AcSVP2 may mimic ABA action [85]. They further indicated that SVP2 was mediated by ABA to decrease meristem activity and prevent premature bud break. DAMs also appear to play a regulatory role in the ABA signaling pathway [85]. Thus, there is increasing evidence that $C B F$ and $D A M$ gene actions are linked with phytohormonal concentration and action in dormancy. The reverse has also been demonstrated in that Knight et al. (2004) earlier showed ABA to upregulate 
$C B F$ expression [86]. Singh et al. (2019) reported that SVL is the ortholog of SVP in aspen (Populus tremula $x$ tremuloides), which mediates photoperiodic dormancy induction via callose synthase, operating downstream of ABA [74]. Singh et al. (2018) also showed ABA induced the expression of the $D A M / S V L$ gene in hybrid aspen [87]. For an excellent recent review, see Liu and Sherif (2019) [25].

In a recent study, analysis of a transformant hybrid aspen (Populus tremula $\mathrm{x}$ tremuloides) showed that expression of $S V L$, a negative regulator of bud break, was down-regulated in hybrid aspen buds after low temperature treatment. It was noted that nonetheless, $S V L$ is similar to DAM genes, clustering closer to $S V P$ in Arabidopsis and apple than to hybrid aspen or peach $D A M$ genes [74, 87]. Interestingly, $S V L$ induced the expression of callose synthase and negatively regulated the gibberellin pathway. Moreover, CBF14 and CBF15 upregulated the GA20x5 gene which deactivates gibberellins in barley [88].

Dormancy is known to be induced primarily by temperature in some fruit species, such as apple and pear [89]. Increasing evidence highlights the role of temperature, especially in the case of northern woody cultivars. While the main regulator of growth cessation and dormancy induction in woody species is short photoperiod, it may be moderated by, and interact with temperature [17]. The increasing confirmation of direct regulation by cold-induced CBFs on DAM gene expression [34, 37, 56], Niu et al. (2016) provided evidence and proposed a model in which CBF induces $D A M$ and DAM downregulates $F T$ which then suppresses growth and stimulates the development of dormancy [38]. Liu and Sherif (2019) further outlined a model integrating multiple phytohormonal networks regulated by DAM [25]. Key among them was the direct suppression by DAM of cytokinins, gibberellins and direct activation by DAM of ABA and callose deposition. Our study provides additional evidence that cytokinin and IAA degradation may be an important regulatory mechanism to endodormancy induction.

\section{Conclusion}

In this study, the differences between the early induction of growth cessation and the depth of endodormancy between two tested poplar cultivars under short photoperiod and low night temperature treatment are associated with the differential expression levels of $C B F 1$ and PtDAM1 genes in buds as well as degradation of growth-promoting phytohormones auxin and cytokinins in leaves. However, since other $D A M$ genes were not examined, we cannot rule out the possibility of other $D A M$ gene involvement.

\section{Methods}

Plant material and dormancy induction conditions

Two hybrid poplar clones, Walker (Populus deltoides var. occidentalis $\times$ Populus petrowskyana) and Okanese $(P$. 'Walker' $\times P$. petrowskyana) (kindly supplied by Raju Soolanayakanahally, Agriculture and Agri-Food Canada) were used in this study - under the same growing conditions as described in Kalcsits et al. (2009) [13]. Briefly, hardwood cuttings were planted in KEKKILÄ DSM $3 \mathrm{~W}$ (Kekkilä Oy, Finland) propagation media (rich in peat and perlite). Approximately $20 \mathrm{~cm}$ long cuttings were placed in each pot $(20 \times 20 \times 20 \mathrm{~cm})$. Before planting, the basal cuttings were dipped in INCIT-8 (Bioplant) rooting stimulating powder. The medium was kept moist during rooting. The hardwood cuttings were grown under LD $\left(18 / 6 \mathrm{~h} \mathrm{light} /\right.$ dark) at $22 / 20^{\circ} \mathrm{C}$ and at $75 \% \mathrm{RH}$ in PGR15 growth chambers (Conviron PGR15, Controlled Environments Ltd., Winnipeg, MB, Canada). Then plants were moved and grown in a greenhouse under natural light at $20 \pm 5{ }^{\circ} \mathrm{C}$, fertilized with Peters Professional 20$10-20(\mathrm{~N}-\mathrm{P}-\mathrm{K})$ fertilizer (diluted to $100 \mathrm{ppm} \mathrm{N}$ ) once a week. Only the 4 strongest, healthiest branches were left on each plant. The rooting and growth period lasted two months. Subsequently, when the branches reached 30 $40 \mathrm{~cm}$ length, the plants were transferred into dormancy inducing conditions in growth chambers of SD conditions $\left(12 / 12 \mathrm{~h}\right.$, light/dark period) at $18 / 3{ }^{\circ} \mathrm{C}$ temperature for 30 days. The length of the light period was then decreased further to 10-h day length for an additional 30 days (60 days in total). These temperature and light conditions ensured dormancy separation responses between Okanese and Walker [13].

\section{Dormancy assessment}

Dormancy development was measured using the budbreak method adapted from Kalcsits et al. (2009) [13]. In brief, small cuttings with two buds were collected from two pots from each genotype. For each genotype and every sampling time-point, 20 branches were cut, so the budburst on 40 buds was examined at given time-point. Cuttings were put in water in glass tubes and kept under LD conditions (18-h daylength) at continuous $22^{\circ} \mathrm{C}$. Samples were collected in every 10th day over the 60 days long experimental induction period. Bud-break was defined as the point when the first leaves started to emerge from the dormant bud, a longer time to budbreak indicates a higher level (i.e. deeper) dormancy. The depth of dormancy $(\triangle \mathrm{DBB})$ was calculated according to Kalcsits et al. (2009) as the difference between the days to bud break between the last and the first sampling days [13]. 


\section{Growth cessation assessment}

The length of the growing branches was measured from the base to the apex every week. Seven pots with 4 branches were measured per genotype. Growth rates $\left(\mathrm{cm}^{*}\right.$ week $\left.{ }^{-1}\right)$ were calculated, and when the growth rates (almost) reached zero, the plants were considered to have stopped their growth period. For these examinations, we use different plants than for gene expression and hormone analysis. These plants were not wounded during the whole experiment.

\section{Gene expression studies}

The youngest fully expanded leaf and mid branch bud samples (about 3 plants per every sampling point altogether 12 leaves and buds were collected) for gene expression studies were collected 4-6 h after the start of the photoperiod and frozen immediately in liquid nitrogen and kept at $-80^{\circ} \mathrm{C}$ till RNA extraction. Samples were homogenized by TissueLyser II (Qiagen) equipment $(29 \mathrm{~Hz}, 1: 30 \mathrm{~min})$, twice. Then $700 \mu \mathrm{l}$ prewarmed elution buffer (3\% CTAB, $1.4 \mathrm{M} \mathrm{NaCl}, 200$ $\mathrm{mM}$ EDTA, $100 \mathrm{mM}$ Tris- $\mathrm{HCl}, 2 \%$ PVPP, 2\% $\beta$ mercaptoethanol and $80 \mu \mathrm{g} / \mathrm{ml}$ proteinase $\mathrm{K}$ ) were added to the homogenates. The tubes were kept at $65^{\circ} \mathrm{C}$ for $10 \mathrm{~min}$. Then $700 \mu \mathrm{l}$ phenol-chloroformisoamyl alcohol (25:24:1) were added. After 5-min centrifugation at 12000 RPM the upper phase was transferred into new tubes. Chloroform-isoamyl alcohol (24:1) was added, and after a new centrifugation step ( $5 \mathrm{~min}$ at $12000 \mathrm{RPM}$ ), the RNA was precipitated by the addition of 0.1 volume of Na-acetate $(3 \mathrm{M}, \mathrm{pH}$ 5.2) and 2 volume of absolute ethyl alcohol. The mixture was uploaded to Direct-zol ${ }^{\mathrm{Tm}}$ RNA MiniPrep kit columns (Zymo Research, Corp., Irvine, CA, USA) and the RNA isolation process was finished according to the manufacturer's instructions. The residual DNA was digested by DNase enzyme and pure RNAs were used for cDNA synthesis. cDNAs were transcribed by M-MLV-RT enzyme (Promega Corporation, Madison, WI, USA) and Oligo $(\mathrm{dT})_{18}$ Primers (Thermo Fisher Scientific Inc., Wilmington, MA, USA). 1500 ng RNA were transcribed into cDNA in $25 \mu \mathrm{l}$ final volume, then diluted to the final volume of $100 \mu \mathrm{l} .1 .0 \mu \mathrm{l}$ cDNA solution was used for every qRT-PCR. The gene expression levels were determined with the CFX96 Touch $^{\text {Tu }}$ Real-Time PCR Detection System (Bio-Rad Hungary Ltd., Budapest, Hungary) using the 2x qPCRBIO SyGreen Blue, Mix Separate ROX (PCR Biosystems Ltd., London, United Kingdom) in $10 \mu \mathrm{l}$ final volume. All the primer sequences, (listed in the Supplemented Table 1), with exception of PtDAM1, were collected from the work of Menon et al. (2015) [58]. The normalized relative gene expression levels were calculated by the $\Delta \Delta \mathrm{Ct}$ method [90]. Ct values were normalized to the $\mathrm{Ct}$ values of the housekeeping Pt18S rRNA gene (Supp. Table 1). Expression level, measured at a given time point, was compared to the expression level measured on the first day for each genotype. The raw $\Delta \Delta \mathrm{Ct}$ values are included in the Supplemented Table 2 .

The relative expression values (fold change) were converted to $\log _{2}$ values, clustered and visualized with the Gitools software on the Supplemented Fig. 2 [91].

\section{Identification of PtDAM1 gene}

For sequence analysis, the Populus trichocarpa reference genome assembly was retrieved from the NCBI Assembly server (https://www.ncbi.nlm.nih.gov/assembly) at proteome level (GCF_000002775.4). Pfam and Hidden Markov Model (HMM) based protein domain search was performed using hmmscan packages of HMMER 3.0 software [92]. The protein collection from the poplar proteome was aligned using a MUSCLE alignment method (Fig. 5) and inferred using Maximum-likelihood phylogenetic tree by MEGA6 software package [93]. Based on the Bayesian Information Criterion (BIC) the best-fit, Jones-Taylor-Thornton (JTT + G) substitution pattern was chosen for the phylogenetic reconstruction. One thousand bootstrap pseudo-replicates were used to test the reliability of the inferred tree.

\section{Hormone analysis}

The youngest fully expanded leaf samples (ca $50 \mathrm{mg} F W$ ) were purified and analyzed according to Dobrev and Kamínek (2002), Dobrev and Vankova (2012) and Svačinova et al. [94-96]. Frozen samples were homogenized and extracted with cold $\left(-20^{\circ} \mathrm{C}\right)$ methanol/water/formic acid $(15 / 4 / 1, \mathrm{v} / \mathrm{v} / \mathrm{v})$. The following isotope-labelled internal standards $(10 \mathrm{pmol} / \mathrm{sample})$ were added: ${ }^{13} \mathrm{C}_{6}$-IAA (Cambridge Isotope Laboratories); ${ }^{2} \mathrm{H}_{4}$-SA (Sigma-Aldrich); ${ }^{2} \mathrm{H}_{3}$-PA, ${ }^{2} \mathrm{H}_{3}$-DPA (NRC-PTI); ${ }^{2} \mathrm{H}_{6}$-ABA, ${ }^{2} \mathrm{H}_{5}$-JA, ${ }^{2} \mathrm{H}_{5}$-transZ, ${ }^{2} \mathrm{H}_{5}$-transZR, ${ }^{2} \mathrm{H}_{5}$-transZ7G, ${ }^{2} \mathrm{H}_{5}$-transZ9G, ${ }^{2} \mathrm{H}_{5}$-transZOG, ${ }^{2} \mathrm{H}_{5}$-transZROG, ${ }^{2} \mathrm{H}_{5}$-transZRMP, ${ }^{2} \mathrm{H}_{3}$ DZ, ${ }^{2} \mathrm{H}_{3}$-DZR, ${ }^{2} \mathrm{H}_{3}$-DZ9G, ${ }^{2} \mathrm{H}_{6}$-iP, ${ }^{2} \mathrm{H}_{6}$-iPR, ${ }^{2} \mathrm{H}_{6}$-iP7G, ${ }^{2} \mathrm{H}_{6}$-iP9G, ${ }^{2} \mathrm{H}_{6}$-iPRMP (Olchemim). Phytohormones were separated with a reverse phase-cation exchange SPE column (Oasis-MCX, Waters) into the acid fraction by elution with methanol [auxins, abscisic acid (ABA), salicylic acid (SA), jasmonic acid (JA)], and into the basic fraction by elution with $0.35 \mathrm{M} \mathrm{NH}_{4} \mathrm{OH}$ in $60 \%$ methanol [cytokinins (CKs)]. Fractions were analyzed using HPLC (Ultimate 3000 , Dionex) coupled to a 3200 Q TRAP hybrid triple quadrupole/linear ion trap mass spectrometer (Applied Biosystems). Hormone quantification was performed by the isotope dilution method with multilevel calibration curves $\left(r^{2}>0.99\right)$. Data processing was performed with the Analyst 1.5 software package (Applied Biosystems). Raw data are included in the Supplemented Table 3. 


\section{Statistical analysis}

One-way ANOVA and Scheffe post hoc test were performed using SPSS 22.0. Because of the unequal variances, Levene's test, the Brown-Forsythe follow up robust tests of equality of means were used. The principal component analysis (PCA) results were obtained by using the Scikit-learn Python module (version 0.23) [97] and Python 3.8. Following mean and variance standardization of the dataset, linear dimensionality reduction was performed by applying singular value decomposition with six extracted components.

\section{Supplementary Information}

The online version contains supplementary material available at https://doi. org/10.1186/s12870-021-02828-7.

Additional file 1: Supplemented Figure 1 Relative expression levels in buds (panel A-E) and in leaves (panel F-K) of the PtCBF1, PtCBF2, PtCBF3, PtCBF4, PtCBF5 and PtCBF6 genes in the Okanese (black bars) and Walker (white bars) genotypes. The expression levels were determined by the $\Delta \Delta \mathrm{Ct}$ method. Pt18S rRNA gene was used as a housekeeping gene for normalization. Mean expression values were normalized per the expression level at the zero sampling time-point, separately for each genotype. The expression values are presented in $\log _{2}$ scale. Error bars represent the \pm SEM originating from 3 biological and 3 technical replicates. 'nd': the expression level was undetectable.

Additional file 2: Supplemented Figure $\mathbf{2}$ Heatmap of the combined phytohormone concentration in leaves $(\mathrm{L})$ and expression of CBFs and DAM genes (leaves ( $L$ ) and buds (B)) in 'Okanese' (Ok) and 'Walker' (Wa) poplar hybrid cultivars over the 60-day short photoperiod and low night temperature growth cessation/dormancy induction treatment. The heatmap was clustered by Euclidean distance. The color bars and letters represent the hierarchy between the investigate gene expression and hormone compound levels.

Additional file 3: Supplemented Table 1 Sequences, melting temperatures and GC contents of the primers used in the study. All the primer sequences listed, with exception of PtDAM1, were collected from the work of Menon et al. (2015) [58].

Additional file 4: Supplemented Table 2 Raw relative gene expression data of the CBF genes.

Additional file 5: Supplemented Table 3 Raw data of hormone analysis.

\section{Abbreviations}

ABA: Abscisic acid; ACC: 1-aminocyclopropane-1-carboxylic acid; BA: Benzoic acid; CBF: C-repeat binding factor protein; CZ: cis-zeatin; CZ7G: Cis-zeatin-7glucoside; cZOG: Cis-zeatin-O-glucoside; CZR: Cis-zeatin riboside; CZROG: Ciszeatin riboside-O-glucoside; DAM: Dormancy-associated MADS-box protein; DBB: Days to bud break; IAA: Indole-3-acetic acid; iP: Isopentenyl adenine; iP7G: Isopentenyl adenine-7-glucoside; iPRPM: Isopentenyl adenosine monophosphate; JA: Jasmonic acid; Ox-IAA: Oxo-IAA; PA: Phaseic acid PCA: Principal component analysis; SA: Salicylic acid; tZ: Trans-zeatin; tZR: Trans-zeatin riboside

\section{Acknowledgements}

For the plant materials, the authors would like to say thank you for Raju Soolanayakanahally who kindly supplied the hardwood cuttings for propagation. The authors would like to say thanks to Mónika E. Fehér for her technical assistance. In the statistical analysis, Dóra Lakatos gave great help and we would like to say thanks for it.

\section{Authors' contributions}

$A ́ B$ and $A S$ contributed equally to this work, collected and analyzed the plant materials as well as prepared the manuscript. KT supported and controlled the whole project with GG. BK established the bioinformatics analysis. ZsM-T helped in the implementation of the experiments. IM contributed to the statistical analysis. The hormone analysis was carried out in the laboratory of RV with the cooperation of PD. All authors take part in the preparing of the manuscript and have read and approved the manuscript.

\section{Funding}

This work was supported by the National Research Development and Innovation Office "NKFIH" grant number K-111879, K-128575 and PD-116564 as well as by the EFOP-3.6.3-VEKOP-16-2017-00008 projects. The project was co-financed by the European Union and the European Social Fund. All of the mentioned funding bodies played no role in the design of the study and collection, analysis, and interpretation of data and in writing the manuscript.

Availability of data and materials

All the relevant data are included in the manuscript and the supplemented materials.

Ethics approval and consent to participate

Not applicable.

\section{Consent for publication}

Not applicable.

\section{Competing interests}

The authors had full access to all study data, take full responsibility for the accuracy of the data analysis, and have authority over manuscript preparation and decisions to submit the manuscript for publication. There is not any competing interest.

\section{Author details}

'Department of Plant Molecular Biology, Agricultural Institute, Centre for Agricultural Research, ELKH, Martonvásár H-2462, Hungary. ²Department of Plant Sciences, College of Agriculture and Bioresources, University of Saskatchewan, Saskatoon SK S7N 5A8, Canada. ${ }^{3}$ Laboratory of Hormonal Regulations in Plants, Institute of Experimental Botany of the Czech Academy of Sciences, Prague 165 02, Czech Republic. ${ }^{4}$ Festetics Doctoral School, Georgikon Campus, Szent István University, Keszthely H-8360, Hungary.

Received: 18 August 2020 Accepted: 6 January 2021

Published online: 24 February 2021

\section{References}

1. Smithberg MH, Weiser CJ. Patterns of variation among climatic races of redosier dogwood. Ecology. 1968:49:495-505. https://doi.org/10.2307/1934116.

2. Kobayashi KD, Fuchigami LH. Modelling temperature effects in breaking rest in red-osier dogwood (Cornus sericea L.)*. Ann Bot. 1983;52:205-15. https:// doi.org/10.1093/oxfordjournals.aob.a086566.

3. Kramer PJ. Effect of variation in length of day on growth and dormancy of trees. Plant Physiol. 1936;11:127-37. https://doi.org/10.1104/pp.11.1.127.

4. Downs R, Borthwick H. Effects of photoperiod on growth of trees. Bot Gaz. 1956;117:310-26.

5. Nitsch J. Photoperiodism in woody plants. Am Soc Hortic Sci. 1957;70:52644.

6. Weiser CJ. Cold Resistance and Injury in Woody Plants: Knowledge of hardy plant adaptations to freezing stress may help us to reduce winter damage. Science. 1970;169:1269-78. https://doi.org/10.1126/science.169.3952.1269.

7. Heide OM. Growth and dormancy in Norway spruce ecotypes (Picea abies) I. interaction of photoperiod and temperature. Physiol Plant. 1974;30:1-12. https://doi.org/10.1111/j.1399-3054.1974.tb04983.x.

8. Junttila O. Effect of photoperiod and temperature on apical growth cessation in two ecotypes of Salix and Betula. Physiol Plant. 1980;48:347-52. https://doi.org/10.1111/j.1399-3054.1980.tb03266.x.

9. Tanino KK, Kalcsits L, Silim S, Kendall E, Gray GR. Temperature-driven plasticity in growth cessation and dormancy development in deciduous woody plants: a working hypothesis suggesting how molecular and cellular function is affected by temperature during dormancy induction. Plant Mol Biol. 2010;73:49-65. https://doi.org/10.1007/s11103-010-9610-y.

10. Svendsen E, Wilen R, Stevenson R, Liu R, Tanino KK. A molecular marker associated with low-temperature induction of dormancy in red osier dogwood (Cornus sericea). Tree Physiol. 2007;27:385-97. https://doi.org/10. 1093/treephys/27.3.385. 
11. Olsen JE, Lee $Y$, Junttila $O$. Effect of alternating day and night temperature on short day-induced bud set and subsequent bud burst in long days in Norway spruce. Front Plant Sci. 2014:1-11. https://doi.org/10.3389/fpls.2014. 00691.

12. Strømme CB, Julkunen-Tiitto R, Olsen JE, Nybakken L. High daytime temperature delays autumnal bud formation in Populus tremula under field conditions. Tree Physiol. 2016;37:71-81. https://doi.org/10.1093/treephys/ tpw089.

13. Kalcsits LA, Silim S, Tanino K. Warm temperature accelerates short photoperiod-induced growth cessation and dormancy induction in hybrid poplar (Populus $\times$ spp.). Trees. 2009;23:971-9. https://doi.org/10.1007/ s00468-009-0339-7.

14. Stinziano JR, Way DA. Autumn photosynthetic decline and growth cessation in seedlings of white spruce are decoupled under warming and photoperiod manipulations. Plant Cell Environ. 2017;40:1296-316. https:// doi.org/10.1111/pce.12917.

15. Lang GA, Early JD, Martin GC, Darnell RL. Endo-, Para-, and ecodormancy: physiological terminology and classification for dormancy research. HortScience (USA). 1987:22:22371-7.

16. Chao WS, Doğramacı M, Horvath DP, Foley ME, Anderson JV. Dormancy Induction and Release in Buds and Seeds. In: Advances in Plant Dormancy. Cham: Springer International Publishing; 2015. p. 235-56. https://doi.org/10. 1007/978-3-319-14451-1_14.

17. Hänninen $\mathrm{H}$, Tanino K. Tree seasonality in a warming climate. Trends Plant Sci. 2011;16:412-6. https://doi.org/10.1016/j.tplants.2011.05.001.

18. Anderson JV, Horvath DP, Chao WS, Foley ME. Bud Dormancy in Perennial Plants: A Mechanism for Survival. In: Dormancy and Resistance in Harsh Environments; 2010. p. 69-90. https://doi.org/10.1007/978-3-642-12422-8_5.

19. Campoy JA, Ruiz D, Egea J. Dormancy in temperate fruit trees in a global warming context: a review. Sci Hortic (Amsterdam). 2011;130:357-72. https://doi.org/10.1016/j.scienta.2011.07.011.

20. Ding J, Nilsson O. Molecular regulation of phenology in trees-because the seasons they are a-changin. Curr Opin Plant Biol. 2016;29:73-9. https://doi. org/10.1016/j.pbi.2015.11.007

21. Singh RK, Svystun T, AIDahmash B, Jönsson AM, Bhalerao RP. Photoperiodand temperature-mediated control of phenology in trees - a molecular perspective. New Phytol. 2017;213:511-24.

22. Maurya JP, Bhalerao RP. Photoperiod- and temperature-mediated control of growth cessation and dormancy in trees: a molecular perspective. Ann Bot. 2017;120:351-60. https://doi.org/10.1093/aob/mcx061.

23. Beauvieux R, Wenden B, Dirlewanger E. Bud Dormancy in Perennial Fruit Tree Species: A Pivotal Role for Oxidative Cues. Front Plant Sci. 2018:1-13. https://doi.org/10.3389/fpls.2018.00657.

24. Wisniewski M, Nassuth A, Arora R. Cold Hardiness in Trees: A Mini-Review. Front Plant Sci. 2018:1-9. https://doi.org/10.3389/fpls.2018.01394.

25. Liu J, Sherif SM. Hormonal Orchestration of Bud Dormancy Cycle in Deciduous Woody Perennials. Front Plant Sci. 2019:1-21. https://doi.org/10. 3389/fpls.2019.01136.

26. Stockinger EJ, Gilmour SJ, Thomashow MF. Arabidopsis thaliana CBF1 encodes an AP2 domain-containing transcriptional activator that binds to the C-repeat/DRE, a cis-acting DNA regulatory element that stimulates transcription in response to low temperature and water deficit. Proc Natl Acad Sci. 1997;94:1035-40. https://doi.org/10.1073/ pnas.94.3.1035.

27. Liu Q, Kasuga M, Sakuma Y, Abe H, Miura S, Yamaguchi-Shinozaki K, et al. Two Transcription Factors, DREB1 and DREB2, with an EREBP/AP2 DNA Binding Domain Separate Two Cellular Signal Transduction Pathways in Drought- and Low- Temperature-Responsive Gene Expression, Respectively, in Arabidopsis. Plant Cell. 1998:1391-406 http://www.plantcell.org/cgi/ content/abstract/10/8/1391.

28. Yamaguchi-Shinozaki K, Shinozaki K. Transcriptional regulatory networks in cellular responses and tolerance to dehydration and cold stresses. Annu Rev Plant Biol. 2006;57:781-803. https://doi.org/10.1146/annurev.arplant.57. 032905.105444.

29. Zhao C, Lang Z, Zhu J-K. Cold responsive gene transcription becomes more complex. Trends Plant Sci. 2015;20:466-8. https://doi.org/10.1016/j.tplants. 2015.06.001.

30. Wisniewski M, Nassuth A, Teulières C, Marque C, Rowland J, Cao PB, et al. Genomics of cold hardiness in Woody plants. CRC Crit Rev Plant Sci. 2014; 33:92-124. https://doi.org/10.1080/07352689.2014.870408.
31. Wisniewski M, Norelli J, Bassett C, Artlip T, Macarisin D. Ectopic expression of a novel peach (Prunus persica) CBF transcription factor in apple (Malus $\times$ domestica) results in short-day induced dormancy and increased cold hardiness. Planta. 2011;233:971-83.

32. Wisniewski M, Norelli J, Artlip T. Overexpression of a peach CBF gene in apple: a model for understanding the integration of growth, dormancy, and cold hardiness in woody plants. Front Plant Sci. 2015:1-13. https://doi.org/ 10.3389/fpls.2015.00085

33. Zhao K, Zhou Y, Ahmad S, Yong X, Xie X, Han Y, et al. PmCBFs synthetically affect $P$ mDAM6 by alternative promoter binding and protein complexes towards the dormancy of bud for Prunus mume. Sci Rep. 2018;8:4527. https://doi.org/10.1038/s41598-018-22537-w

34. Zhao K, Zhou Y, Li Y, Zhuo X, Ahmad S, Han Y, et al. Crosstalk of PmCBFs and PmDAMs based on the changes of Phytohormones under seasonal cold stress in the stem of Prunus mume. Int J Mol Sci. 2018;19:15. https://doi. org/10.3390/ijms19020015.

35. Benedict $C$, Skinner JS, Meng $R$, Chang $Y$, Bhalerao R, Huner NPA, et al. The CBF1-dependent low temperature signalling pathway, regulon and increase in freeze tolerance are conserved in Populus spp. Plant Cell Environ. 2006: 29:1259-72. https://doi.org/10.1111/j.1365-3040.2006.01505.X.

36. Zhang Z, Zhuo X, Zhao K, Zheng T, Han Y, Yuan C, et al. Transcriptome profiles reveal the crucial roles of hormone and sugar in the bud dormancy of Prunus mume. Sci Rep. 2018;8:5090. https://doi.org/10.1038/s41598-01823108-9.

37. Li J, Yan X, Yang Q, Ma Y, Yang B, Tian J, et al. PpCBFs selectively regulate PpDAMs and contribute to the pear bud endodormancy process. Plant Mol Biol. 2019;99:575-86. https://doi.org/10.1007/s11103-019-00837-7.

38. Niu Q, Li J, Cai D, Qian M, Jia H, Bai S, et al. Dormancy-associated MADS-box genes and microRNAs jointly control dormancy transition in pear (Pyrus pyrifolia white pear group) flower bud. J Exp Bot. 2016;67:239-57.

39. Horvath D. Common mechanisms regulate flowering and dormancy. Plant Sci. 2009;177:523-31. https://doi.org/10.1016/j.plantsci.2009.09.002.

40. Rodriguez AJ, Sherman WB, Scorza R, Wisniewski M, Okie WR. "Evergreen" peach, its inheritance and dormant behavior. J Am Soc Hortic Sci. 1994;119: 789-92.

41. Bielenberg DG, Wang Y, Fan S, Reighard GL, Scorza R, Abbott AG. A deletion affecting several gene candidates is present in the Evergrowing peach mutant. J Hered. 2004;95:436-44. https://doi.org/10.1093/jhered/esh057.

42. Bielenberg DG, Eileen WY, Li Z, Zhebentyayeva T, Fan S, Reighard GL, et al. Sequencing and annotation of the evergrowing locus in peach [Prunus persica (L.) Batsch] reveals a cluster of six MADS-box transcription factors as candidate genes for regulation of terminal bud formation. Tree Genet Genomes. 2008:4:495-507. https://doi.org/10.1007/s11295-007-0126-9.

43. Horvath DP. Dormancy-associated MADS-BOX genes: a review. In: Advances in plant dormancy. Cham: Springer International Publishing; 2015. p. $137-$ 46. https://doi.org/10.1007/978-3-319-14451-1_7

44. da Silveira Falavigna V, Guitton B, Costes E, Andrés F. I Want to (Bud) Break Free: The Potential Role of DAM and SVP-Like Genes in Regulating Dormancy Cycle in Temperate Fruit Trees. Front Plant Sci. 2019:1-17. https://doi.org/10.3389/fpls.2018.01990.

45. Li Z, Reighard GL, Abbott AG, Bielenberg DG. Dormancy-associated MADS genes from the EVG locus of peach [Prunus persica (L.) Batsch] have distinct seasonal and photoperiodic expression patterns. J Exp Bot. 2009;60:3521-30. https://doi.org/10.1093/jxb/erp195.

46. Jiménez S, Li Z, Reighard GL, Bielenberg DG. Identification of genes associated with growth cessation and bud dormancy entrance using a dormancy-incapable tree mutant. BMC Plant Biol. 2010;10:25. https://doi.org/ 10.1186/1471-2229-10-25.

47. Sasaki R, Yamane H, Ooka $T$, Jotatsu H, Kitamura Y, Akagi T, et al. Functional and expressional analyses of PmDAM genes associated with endodormancy in Japanese apricot. Plant Physiol. 2011;157:485-97.

48. Mimida N, Saito T, Moriguchi T, Suzuki A, Komori S, Wada M. Expression of DORMANCY-ASSOCIATED MADS-BOX (DAM)-like genes in apple. Biol Plant. 2015:59:237-44. https://doi.org/10.1007/s10535-015-0503-4.

49. Ubi BE, Sakamoto D, Ban Y, Shimada T, Ito A, Nakajima I, et al. Molecular cloning of dormancy-associated MADS-box gene homologs and their characterization during seasonal endodormancy transitional phases of Japanese pear. J Am Soc Hortic Sci. 2010;135:174-82.

50. Saito T, Bai S, Ito A, Sakamoto D, Saito T, Ubi BE, et al. Expression and genomic structure of the dormancy-associated MADS box genes MADS13 
in Japanese pears (Pyrus pyrifolia Nakai) that differ in their chilling requirement for endodormancy release. Tree Physiol. 2013;33:654-67.

51. Chen K-Y. Type II MADS-BOX genes associated with poplar apical bud development and dormancy: University of Maryland; 2008. https://drum.lib. umd.edu/handle/1903/8152

52. Horvath DP, Sung S, Kim D, Chao W, Anderson J. Characterization, expression and function of DORMANCY ASSOCIATED MADS-BOX genes from leafy spurge. Plant Mol Biol. 2010;73:169-79. https://doi.org/10.1007/ s11103-009-9596-5.

53. Howe GT, Horvath DP, Dharmawardhana P, Priest HD, Mockler TC, Strauss SH. Extensive Transcriptome changes during natural onset and release of vegetative bud dormancy in Populus. Front Plant Sci. 2015;6:1-28. https:// doi.org/10.3389/fpls.2015.00989.

54. Balogh E, Halász J, Soltész A, Erös-Honti Z, Gutermuth Á, Szalay L, et al Identification, Structural and Functional Characterization of Dormancy Regulator Genes in Apricot (Prunus armeniaca L.). Front Plant Sci. 2019:1-16. https://doi.org/10.3389/fpls.2019.00402.

55. Horvath DP, Kudrna D, Talag J, Anderson JV, Chao WS, Wing R, et al. BAC Library Development and Clone Characterization for Dormancy-Responsive DREB4A, DAM, and FT from Leafy Spurge (Euphorbia esula) Identifies Differential Splicing and Conserved Promoter Motifs. Weed Sci. 2013;61:3039. https://doi.org/10.1614/WS-D-12-00175.1.

56. Saito T, Bai S, Imai T, Ito A, Nakajima I, Moriguchi T. Histone modification and signalling cascade of the dormancy-associatedMADS-box gene, PpMADS13-1, in Japanese pear (Pyrus pyrifolia) during endodormancy. Plant Cell Environ. 2015;38:1157-66.

57. Perry TO. Dormancy of Trees in Winter. Science. 1971;171:29-36. https://doi. org/10.1126/science.171.3966.29.

58. Menon M, Barnes WJ, Olson MS. Population genetics of freeze tolerance among natural populations of Populus balsamifera across the growing season. New Phytol. 2015;207:710-22. https://doi.org/10.1111/nph.13381.

59. Urrestarazu J, Muranty H, Denancé C, Leforestier D, Ravon E, Guyader A et al. Genome-wide association mapping of flowering and ripening periods in apple. Front Plant Sci. 2017;8:1923. https://doi.org/10.3389/fpls.2017. 01923.

60. Wells CE, Vendramin E, Jimenez Tarodo S, Verde I, Bielenberg DG. A genomewide analysis of MADS-box genes in peach [Prunus persica (L.) Batsch]. BMC Plant Biol. 2015;15:41. https://doi.org/10.1186/s12870-015-0436-2.

61. Tuskan GA, DiFazio S, Jansson S, Bohlmann J, Grigoriev I, Hellsten U, et al. The Genome of Black Cottonwood, Populus trichocarpa (Torr. \& Gray). Science. 2006:313:1596-604. https://doi.org/10.1126/science.1128691.

62. Yamane H, Ooka T, Jotatsu H, Hosaka Y, Sasaki R, Tao R. Expressional regulation of PPDAM5 and PPDAM6, peach (Prunus persica) dormancyassociated MADS-box genes, by low temperature and dormancy-breaking reagent treatment. J Exp Bot. 2011;62:3481-8. https://doi.org/10.1093/jxb/ err028.

63. Jiménez S, Reighard GL, Bielenberg DG. Gene expression of DAM5 and DAM6 is suppressed by chilling temperatures and inversely correlated with bud break rate. Plant Mol Biol. 2010;73:157-67.

64. Ruttink T, Arend M, Morreel K, Storme V, Rombauts S, Fromm J, et al. A molecular timetable for apical bud formation and dormancy induction in poplar. Plant Cell. 2007;19:2370-90. https://doi.org/10.1105/tpc.107.052811.

65. Chao WS, Foley ME, Horvath DP, Anderson JV. Signals regulating dormancy in vegetative buds. Int J Plant Dev Biol. 2007;1:49-56.

66. Cooke JEK, Eriksson ME, Junttila O. The dynamic nature of bud dormancy in trees: environmental control and molecular mechanisms. Plant Cell Environ. 2012;35:1707-28. https://doi.org/10.1111/j.1365-3040.2012.02552.x.

67. Tanino KK. Hormones and Endodormancy induction in Woody plants. J Crop Improv. 2004;10:157-99. https://doi.org/10.1300/J411v10n01_08.

68. Wingler A. Comparison of signaling interactions determining annual and perennial plant growth in response to low temperature. Front Plant Sci. 2015:1-9. https://doi.org/10.3389/fpls.2014.00794.

69. Hemberg T. Growth-inhibiting substances in terminal buds of Fraxinus. Physiol Plant. 1949;2:37-44. https://doi.org/10.1111/j.1399-3054.1949.tb07646.x

70. Dennis F, Edgerton L. The relationship between an inhibitor and rest in peach flower buds. Am Soc Hortic Sci. 1961;77:107-16.

71. Eagles CF, Wareing PE. The role of growth substances in the regulation of bud dormancy. Physiol Plant. 1964;17:697-709. https://doi.org/10.1111/j. 1399-3054.1964.tb08196.x.

72. Olsen JE, Junttila O, Nilsen J, Eriksson ME, Martinussen I, Olsson O, et al. Ectopic expression of oat phytochrome a in hybrid aspen changes critical daylength for growth and prevents cold acclimatization. Plant J. 1997;12: 1339-50. https://doi.org/10.1046/j.1365-313x.1997.12061339.x.

73. Tylewicz S, Petterle A, Marttila S, Miskolczi P, Azeez A, Singh RK, et al. Photoperiodic control of seasonal growth is mediated by ABA acting on cell-cell communication. Science. 2018;360:212-5. https://doi.org/10.1126/ science.aan8576.

74. Singh RK, Miskolczi P, Maurya JP, Bhalerao RP. A Tree Ortholog of SHORT VEGETATIVE PHASE Floral Repressor Mediates Photoperiodic Control of Bud Dormancy. Curr Biol. 2019;29:128-33.e2. https://doi.org/10.1016/j.cub.2018. 11.006.

75. Kosová K, Prášil IT, Vítámvás P, Dobrev P, Motyka V, Floková K, et al. Complex phytohormone responses during the cold acclimation of two wheat cultivars differing in cold tolerance, winter Samanta and spring Sandra. J Plant Physiol. 2012;169:567-76. https://doi.org/10.1016/j.jplph.2011. 12.013.

76. Djilianov DL, Dobrev PI, Moyankova DP, Vankova R, Georgieva DT, Gajdošová S, et al. Dynamics of endogenous Phytohormones during desiccation and recovery of the resurrection plant species Haberlea rhodopensis. J Plant Growth Regul. 2013;32:564-74. https://doi.org/10.1007/ s00344-013-9323-y.

77. Hu Y, Jiang $L$, Wang $F, Y u$ D. Jasmonate regulates the INDUCER OF CBF EXPRESSION-C-REPEAT BINDING FACTOR/DRE BINDING FACTOR1 Cascade and freezing tolerance in Arabidopsis. Plant Cell. 2013;25:2907-24. https:// doi.org/10.1105/tpc.113.112631.

78. Achard P, Gong F, Cheminant S, Alioua M, Hedden P, Genschik P. The coldinducible CBF1 factor-dependent signaling pathway modulates the accumulation of the growth-repressing DELLA proteins via its effect on gibberellin metabolism. Plant Cell. 2008;20:2117-29. https://doi.org/10.1105/ tpc.108.058941.

79. Hou X, Lee LYC, Xia K, Yan Y, Yu H. DELLAs modulate Jasmonate signaling via competitive binding to JAZs. Dev Cell. 2010;19:884-94. https://doi.org/ 10.1016/j.devcel.2010.10.024.

80. Um TY, Lee HY, Lee S, Chang SH, Chung PJ, Oh K-B, et al. Jasmonate ZimDomain Protein 9 Interacts With Slender Rice 1 to Mediate the Antagonistic Interaction Between Jasmonic and Gibberellic Acid Signals in Rice. Front Plant Sci. 2018:1-11. https://doi.org/10.3389/fpls.2018.01866.

81. Gondor OK, Szalai G, Kovács V, Janda T, Pál M. Relationship between polyamines and other cold-induced response mechanisms in different cereal species. J Agron Crop Sci. 2016;202:217-30. https://doi.org/10.1111/ jac.12144.

82. Baldwin BD, Bandara MS, Tanino KK. Bud scale maturation in Saskatoon Berry (Amelanchier alnifolia Nutt.) plantlets following in vitro hormonal treatments. Acta Hortic. 2000:203-8. https://doi.org/10.17660/ActaHortic. 2000.520.21

83. Tuan PA, Bai S, Saito T, Ito A, Moriguchi T. Dormancy-Associated MADS-Box (DAM) and the Abscisic acid pathway regulate pear Endodormancy through a feedback mechanism. Plant Cell Physiol. 2017;58:1378-90. https://doi.org/ 10.1093/pcp/pcx074.

84. Wu R, Wang T, Warren BAW, Allan AC, Macknight RC, Varkonyi-Gasic E. Kiwifruit SVP2 gene prevents premature budbreak during dormancy. J Exp Bot. 2017:68:1071-82. https://doi.org/10.1093/jxb/erx014.

85. Wu R, Wang T, Warren BAW, Thomson SJ, Allan AC, Macknight RC, et al. Kiwifruit SVP2 controls developmental and drought-stress pathways. Plant Mol Biol. 2018;96:233-44. https://doi.org/10.1007/s11103017-0688-3.

86. Knight H, Zarka DG, Okamoto H, Thomashow MF, Knight MR. Abscisic acid induces CBF gene transcription and subsequent induction of cold-regulated genes via the CRT promoter element. Plant Physiol. 2004;135:1710-7. https://doi.org/10.1104/pp.104.043562.

87. Singh RK, Maurya JP, Azeez A, Miskolczi P, Tylewicz S, Stojkovič K, et al. A genetic network mediating the control of bud break in hybrid aspen. Nat Commun. 2018;9:4173. https://doi.org/10.1038/s41467-018-06696-y.

88. Soltész A, Smedley M, Vashegyi I, Galiba G, Harwood W, Vágújfalvi A. Transgenic barley lines prove the involvement of TaCBF14 and TaCBF15 in the cold acclimation process and in frost tolerance. J Exp Bot. 2013;64:184962. https://doi.org/10.1093/jxb/ert050.

89. Heide OM, Prestrud AK. Low temperature, but not photoperiod, controls growth cessation and dormancy induction and release in apple and pear. Tree Physiol. 2005;25:109-14. https://doi.org/10.1093/treephys/25.1.109. 
90. Livak KJ, Schmittgen TD. Analysis of relative gene expression data using real-time quantitative $P C R$ and the $2^{-\Delta \Delta C}$ method. Methods. 2001;25:402-8. https://doi.org/10.1006/meth.2001.1262.

91. Perez-Llamas C, Lopez-Bigas N. Gitools: analysis and visualisation of genomic data using interactive heat-maps. PLoS One. 2011;6:e19541. https://doi.org/10.1371/journal.pone.0019541.

92. Eddy SR. A new generation of homology search tools based on probabilistic inference. Genome Informatics. 2009;23:205-11. https://doi.org/ 10.1142/9781848165632_0019.

93. Tamura K, Stecher G, Peterson D, Filipski A, Kumar S. MEGA6: molecular evolutionary genetics analysis version 6.0. Mol Biol Evol. 2013;30:2725-9. https://doi.org/10.1093/molbev/mst197.

94. Ivanov Dobrev P, Kamínek M. Fast and efficient separation of cytokinins from auxin and abscisic acid and their purification using mixed-mode solidphase extraction. J Chromatogr A. 2002;950:21-9. https://doi.org/10.1016/ S0021-9673(02)00024-9.

95. Dobrev PI, Vankova R. Quantification of abscisic acid, cytokinin, and auxin content in salt-stressed plant tissues. In: Shabala S, Cuin TA, editors. Plant Salt Tolerance. Totowa: Humana Press; 2012. p. 251-61. https://doi.org/10. 1007/978-1-61779-986-0_17.

96. Svačinova J, Novák O, Plačková L, Lenobel R, Holík J, Strnad M, et al. A new approach for cytokinin isolation from Arabidopsis tissues using miniaturized purification: pipette tip solid-phase extraction. Plant Methods. 2012;8:17.

97. Pedregosa F, Varoquaux G, Gramfort A, Michel V, Thirion B, Grisel O, et al. Scikit-learn: machine learning in Python. J Mach Learn Res. 2011;12:2825-30. https://doi.org/10.1145/2786984.2786995.

\section{Publisher's Note}

Springer Nature remains neutral with regard to jurisdictional claims in published maps and institutional affiliations.

Ready to submit your research? Choose BMC and benefit from:

- fast, convenient online submission

- thorough peer review by experienced researchers in your field

- rapid publication on acceptance

- support for research data, including large and complex data types

- gold Open Access which fosters wider collaboration and increased citations

- maximum visibility for your research: over $100 \mathrm{M}$ website views per year

At BMC, research is always in progress.

Learn more biomedcentral.com/submissions 